Article

\title{
Postharvest Losses in Quantity and Quality of Table Grape (cv. Crimson Seedless) along the Supply Chain and Associated Economic, Environmental and Resource Impacts
}

\author{
Anelle Blanckenberg ${ }^{1,2}$, Umezuruike Linus Opara ${ }^{2, *(\mathbb{D})}$ and Olaniyi Amos Fawole $2,3, *(\mathbb{D}$ \\ 1 Department of Horticultural Sciences, Faculty of AgriSciences, Stellenbosch University, \\ Stellenbosch 7600, South Africa; 12938033@sun.ac.za \\ 2 Africa Institute of Postharvest Technology, South African Research Chair in Postharvest Technology, \\ Department of Horticultural Sciences, Faculty of AgriSciences, Stellenbosch University, \\ Stellenbosch 7600, South Africa \\ 3 Postharvest Research Laboratory, Department of Botany and Plant Biotechnology, \\ University of Johannesburg, P.O. Box 524, Auckland Park, Johannesburg 2006, South Africa \\ * Correspondence: opara@sun.ac.za (U.L.O.); olaniyi@sun.ac.za (O.A.F.)
}

\section{check for} updates

Citation: Blanckenberg, A.; Opara, U.L.; Fawole, O.A. Postharvest Losses in Quantity and Quality of Table Grape (cv. Crimson Seedless) along the Supply Chain and Associated Economic, Environmental and Resource Impacts. Sustainability 2021, 13, 4450. https://doi.org/10.3390/ su13084450

Academic Editors: Alessandro Suardi and Nadia Palmieri

Received: 8 March 2021

Accepted: 7 April 2021

Published: 16 April 2021

Publisher's Note: MDPI stays neutral with regard to jurisdictional claims in published maps and institutional affiliations.

Copyright: (C) 2021 by the authors Licensee MDPI, Basel, Switzerland. This article is an open access article distributed under the terms and conditions of the Creative Commons Attribution (CC BY) license (https:/ / creativecommons.org/licenses/by/ $4.0 /)$.

\begin{abstract}
High incidence of postharvest losses is a major challenge to global food security. Addressing postharvest losses is a better strategy to increase business efficiency and improve food security rather than simply investing more resources to increase production. Global estimates show that fruit and vegetables are the highest contributors to postharvest losses and food waste, with $45 \%$ of production lost. This represents $38 \%$ of total global food losses and waste. However, the lack of primary data on postharvest losses at critical steps in the fruit value chain and the unknown economic, environmental and resource impacts of these losses makes it difficult to formulate mitigation strategies. This paper quantifies postharvest losses and quality attributes of 'Crimson Seedless' table grapes at farm and simulated retail levels. Table grapes were sampled from four farms in the Western Cape Province of South Africa, the largest deciduous fruit production and export region in Southern Africa. Mean onfarm losses immediately after harvest was $13.9 \%$ in 2017 and 5.97\% in 2018, ranging from 5.51\% to $23.3 \%$ for individual farms. The main reason for on-farm losses was mechanical damage (7.1\%). After 14 days in cold storage $\left(-0.3 \pm 0.7{ }^{\circ} \mathrm{C}, 81.3 \pm 4.1 \% \mathrm{RH}\right)$, mean grape losses were $3.05 \%$ in 2017 and $2.41 \%$ in 2018, which increased to $7.41 \%$ in 2017 and $2.99 \%$ in 2018, after 28 days. After 10 days of further storage under simulated market conditions $\left(5.4 \pm 0.6{ }^{\circ} \mathrm{C}, 83.7 \pm 2.9 \% \mathrm{RH}\right)$, fruit losses were $3.65 \%$ during retail marketing and $4.36 \%$ during export. Storing grapes under ambient conditions $\left(25.1 \pm 1.3{ }^{\circ} \mathrm{C}\right.$ and $\left.46.6 \pm 6.0 \% \mathrm{RH}\right)$ resulted in a higher incidence of losses, increasing from 7.03 to 9.59 and $14.29 \%$ after 3, 7 and 10 days, respectively. The socioeconomic impacts of these postharvest losses amounted to financial losses of over ZAR 279 million (USD 17 million according to the conversion rate of 20 October 2020) annually, and this was associated with the loss of 177.43 million $\mathrm{MJ}$ of fossil energy, 4.8 million $\mathrm{m}^{3}$ of fresh water and contributed to the emission of approximately 52,263 tons of $\mathrm{CO}_{2}$ equivalent.
\end{abstract}

Keywords: postharvest losses; food waste; physicochemical properties; table grape; shelf-life; decay; stem browning; $\mathrm{SO}_{2}$ damage; socioeconomic impacts

\section{Introduction}

Interest in the mitigation of postharvest losses is heightened due to global concern about food insecurity. Preserving the food supply after production has since the earliest times been a problem for humankind [1]. However, a dominant challenge of the 21st century is how to feed the growing world population sustainably, predicted to reach 9.1 billion by 2050 , affordably while using the natural resources required equitably and sustainably $[2,3]$. 
The UN Food and Agriculture Organization (FAO) estimated that feeding the growing world population by 2050 would require $70 \%$ increase in food production [4]. However, the FAO also reports that approximately one-third of the edible portions of the food produced globally is lost or wasted along the supply chain, from farm to plate [5], with a total of $38 \%$ of the volume consisting of fruits and vegetables [6]. Lost and wasted food consumes a quarter of all the water used by agriculture annually, requires farmland area the size of China, and generates an estimated $8 \%$ of global greenhouse gas emissions. In effect, if lost and wasted food were a country, it would be the third-largest greenhouse gas emitter on the planet after China and the United States [7-9].

While $95 \%$ of all agricultural research investment focuses on increasing crop production strategies, only 5\% focuses on postharvest issues [10]. Reducing postharvest loss and waste is more cost effective and less time consuming than production strategies. Therefore, the improvement of postharvest chains must receive as much attention as production practices. Furthermore, limiting the loss of fresh fruit will reduce the use of land, chemicals, energy, and other inputs needed to produce horticultural crops, thereby conserving natural resources and protecting the environment [11,12].

A major obstacle in achieving postharvest loss mitigation is a lack of clear knowledge of the real magnitudes of losses, making it impossible to measure progress against any loss reduction targets [13].

Apart from worrying anecdotal information, there is little scientific data available about food losses in South Africa. A study [14] provided a preliminary estimate of the magnitude of food loss and waste generation in South Africa of around 9.04 million tons per year. However, this study was based on available data as reported by FAO and further assumptions as no primary data was collected. While estimates do indicate the size of the problem, they do not provide accurate and reliable data for specific supply chains.

The lack of primary data on postharvest losses at critical steps in the fruit value chain and the unknown economic, environmental and resource impacts makes it challenging to formulate mitigation strategies. There is a lack of standard methods to measure postharvest losses of food crops, including fruit and vegetable crops. Researchers have developed many different methods during the past few decades, focusing on different aspects of the value chain and varying types of food losses [15]. The lack of accurate and reliable postharvest loss data may result in inaccurate assumptions on food wastage [16].

In South Africa, fruit and vegetables account for $47 \%$ of food wastage [14]. In the first South African study generating primary data on postharvest losses of vegetables at the retail level, the authors [12] found vegetable losses for carrot, tomato and cabbages to be on average $17.93 \%, 15.33 \%$ and $21.21 \%$, respectively. There are currently no primary research data on the magnitude of losses in the fresh fruit value chain.

Fruit is a major contributor to the agricultural industry, considering foreign exchange earnings and employment creation.

Table grapes account for $32 \%$ of the total area planted to deciduous fruits in South Africa [17], with 'Crimson Seedless' cultivar accounting for 20\% of all vines [18]. 'Crimson Seedless' is a mid to late season red seedless grape cultivar with firm berries characterized by its crisp texture and intensely sweet flavor. The main quality problems during postharvest handling are moisture loss leading to loss of mass, fungal infection and shriveled rachis, which then become brittle and break easily, and the browning of the stems, which reduces the visual appeal and price of the product [19-21].

Although table grapes are nonclimacteric fruit with a relatively low rate of physiological activity [22], they are subject to severe postharvest losses during storage and long distance transport [23]. Rapid moisture loss, which results in rachis (cluster stem) drying and browning [24,25], mass loss [26], berry shatter, wilting and shriveling of berries [27] are some of the main quality problems experienced during postharvest handling causing quantitative and quality losses. It has been suggested that inappropriate handling processes are the main reason for weakening the natural defenses of grapes and making fresh grapes more susceptible to decay and subsequent deterioration [28]. 
As the gross value of production of table grapes has increased significantly from R2 billion in 2006/07 to R7.1 billion in 2015/16, an increase of 248\% [17], reduction of postharvest losses by even a few percentage points will not only reduce the cost of production, trade and distribution but will also have significant financial implications for all involved in the supply chain by lowering the price for the consumer and increasing the farmers' income. Therefore, this research aimed to fill a gap in the knowledge by generating primary data on postharvest losses at critical steps in the supply chain for table grape 'Crimson Seedless' to inform future action to reduce and better manage the food waste problem.

\section{Materials and Methods}

\subsection{Harvesting Techniques and Berry Preparation}

Data collection protocols were similar to those used by [29]. Grapes were harvested from four farms during the last week of February and the first week of March in 2017, and during the first three weeks of February in 2018. Both times were during the commercial harvest. In 2017 a total sample size of 1200 bunches ( 300 bunches per farm) were collected, while 1600 bunches (400 bunches per farm) were collected in 2018. The grapes were collected from four farms that each have their own packhouse on site, near De Doorns, Robertson and Piketberg in the Western Cape Region of South Africa. Bunches were weighed in the packhouse as they came in from the vineyard, each bunch was then tagged with a unique label identifying the farm of origin $(\mathrm{V} ; \mathrm{K} ; \mathrm{R}$ or $\mathrm{D})$, the supply chain scenario the bunch was destined for (A; B; or C in 2017 and A; B; C or D in 2018) and the bunch number (1-100) e.g., VA29 (Table 1).

Table 1. Description of the supply chain scenarios studied.

\begin{tabular}{|c|c|c|}
\hline Supply Chain Scenario & Description & Environmental Condition \\
\hline A & $\begin{array}{l}\text { Table grapes were harvested and stored } \\
\text { under ambient conditions, typical in areas } \\
\text { that lack cold storage facilities } \\
\text { Measurements were taken at harvest and } \\
\text { after } 3,7 \text { and } 10 \text { days }\end{array}$ & $\begin{array}{c}\text { Under ambient conditions for } 10 \text { days: } \\
25.1 \pm 1.3^{\circ} \mathrm{C} \\
46.6 \pm 6.0 \% \mathrm{RH}\end{array}$ \\
\hline $\mathrm{B}$ & $\begin{array}{c}\text { Handling of table grapes for domestic } \\
\text { supply chain } \\
\text { Measurements were taken at harvest, after } \\
14 \text { days in cold storage, after } 10 \text { days at retail } \\
\text { conditions and then after } 3,7 \text { and } 10 \text { days at } \\
\text { ambient conditions }\end{array}$ & $\begin{array}{l}\text { Cold store for } 2 \text { weeks: }-0.3^{\circ} \mathrm{C} \pm 0.7^{\circ} \mathrm{C} \text { and } \\
81.3 \% \pm 4.1 \% \mathrm{RH} \\
\text { Retail store for } 10 \text { days: } 5.4^{\circ} \mathrm{C} \pm 0.6^{\circ} \mathrm{C} \text { and } \\
83.7 \% \pm 2.9 \% \mathrm{RH} \\
\text { Consumer } / \text { home (ambient) store: } \\
25.1 \pm 1.3^{\circ} \mathrm{C} \text { and } 46.6 \pm 6.0 \% \mathrm{RH}\end{array}$ \\
\hline $\mathrm{C}$ & $\begin{array}{c}\text { Shipping to export markets } \\
\text { Measurements were taken at harvest, after } \\
28 \text { days in cold storage, after a further } \\
10 \text { days at retail conditions and then at } 3 \text {, } \\
7 \text { and } 10 \text { days at ambient conditions }\end{array}$ & $\begin{array}{l}\text { Cold storage for } 4 \text { weeks at }-0.3 \pm 0.7^{\circ} \mathrm{C} \text {, } \\
\qquad 1.3 \pm 4.1 \% \mathrm{RH} \\
\text { Retail store for } 10 \text { days: } 5.4^{\circ} \mathrm{C} \pm 0.6^{\circ} \mathrm{C} \text { and } \\
83.7 \% \pm 2.9 \% \mathrm{RH} \\
\text { Consumer } / \text { home (ambient) 'shelf' store: } \\
25.1 \pm 1.3^{\circ} \mathrm{C} \text { and } 46.6 \pm 6.0 \% \mathrm{RH}\end{array}$ \\
\hline $\mathrm{D}$ & $\begin{array}{l}\text { Reefer container containing export fruit are } \\
\text { left open on arrival for } 2 \text { days before fruit is } \\
\text { unloaded. 'Abusive' treatment of fruit within } \\
\text { the export chain } \\
\text { Measurements were taken at harvest, after } \\
28 \text { days in cold storage then after } 2 \text { days } \\
\text { exposure to ambient conditions, after a } \\
\text { further } 10 \text { days at retail conditions and then } \\
\text { at } 3,7 \text { and } 10 \text { days at ambient conditions }\end{array}$ & $\begin{array}{c}\text { Cold store for } 2 \text { weeks: }-0.3{ }^{\circ} \mathrm{C} \pm 0.7^{\circ} \mathrm{C} \text { and } \\
81.3 \% \pm 4.1 \% \mathrm{RH} ; \\
\text { Ambient storage for } 2 \text { days: } 25.1 \pm 1.3^{\circ} \mathrm{C} \\
46.6 \pm 6.0 \% \mathrm{RH} ; \\
\text { Retail store display for } 10 \text { days: } \\
5.4^{\circ} \mathrm{C} \pm 0.6^{\circ} \mathrm{C} \text { and } 83.7 \% \pm 2.9 \% \mathrm{RH} ; \\
\text { Consumer } / \text { home (ambient) 'shelf' store: } \\
25.1 \pm 1.3^{\circ} \mathrm{C} \text { and } 46.6 \pm 6.0 \% \mathrm{RH}\end{array}$ \\
\hline
\end{tabular}

The grape bunches were then trimmed by expert packers according to commercial practice and packed into standard 9-kg cartons (internal dimensions of the 9-kg boxes were $58 \mathrm{~cm}$ long $\times 34 \mathrm{~cm}$ wide $\times 13.2 \mathrm{~cm}$ high) with a riffled sheet at the bottom, a plastic liner 
as well as an $\mathrm{SO}_{2}$ cover pad on top with a slow release of sodium metabisulfite $\left(\mathrm{Na}_{2} \mathrm{~S}_{2} \mathrm{O}_{5}\right)$ (Uvasys ${ }^{\circledR}$, Cape Town, South Africa). Sodium metabisulfite generates sulphurous anhydride gas $\left(\mathrm{SO}_{2}\right)$ when in contact with humidity, inhibiting the development and growth of fungi in table grapes during refrigerated packaging and transport.

\subsection{Supply Chains Simulated}

In 2017, 18 cartons per farm were collected and divided equally into three simulated supply chain scenarios. In 2018, 24 cartons per farm were collected and divided into four simulated supply chain scenarios. From each farm and for both years, 100 bunches were used for each supply chain scenario simulated, i.e., 400 bunches per scenario. Four supply chain scenarios were studied (Table 1), representing the range of postharvest handling practices that occur in local and export marketing of table grapes in the South African fresh fruit industry. According to export grape producers (pers. communication Amelia Vorster, Technical Advisor (Quality) - Karsten Western Cape), scenario D is a common occurrence and leads to tension between role-players as to whether the fruit was mishandled before the report was written and who is responsible for the losses if it is higher than expected.

\subsection{Fruit Loss Evaluation and Quality Measurements}

\subsubsection{Postharvest Losses}

The base measurement for losses at harvest occurred in the packhouse on each farm after the bunches were trimmed for packaging and the resulting berries sorted into categories based on the reason for being cut from the bunch, (1) berry too green in color, (2) mechanical damage or (3) decayed. It was quantified as the weight of the berries removed as a percentage of the original weight of the bunches before trimming. At each evaluation date thereafter, physical losses were quantified as the decrease in bunch weight and the amount lost due to decay or $\mathrm{SO}_{2}$ damage (a high concentration of $\mathrm{SO}_{2}$ can damage table grapes by causing bleaching, cracking or causing early browning of the rachis) expressed as a percentage of the initial berry numbers per bunch.

\subsubsection{Quality Attributes}

The following attributes were measured at each evaluation time:

1. Weight loss

Expressed as a percentage of the initial bunch weight. 30 bunches $\times 4$ farms $=120$ bunches per supply chain scenario.

2. Stem browning

Rated on a 5-point scale, with 1 being fresh/green and 5 being dry/brown $[15,16]$. In total, 30 bunches $\times 4$ farms $=120$ bunches per supply chain scenario.

3. Total soluble solids (TSS) concentration

Fruit juice was extracted using a manual juice extractor $\left(\mathrm{TMS}^{\circledR}\right.$ hand press commercial pro manual juice squeezer). TSS of juice was measured with a digital refractometer (Atago, Tokyo, Japan). A total of 12 bunches per supply chain scenario were used.

4. Titratable acidity (TA)

TA of juice was determined by titration to $\mathrm{pH} 8.2$ using a Metrohm 862 compact titrosampler (Herisau, Switzerland). A total of 12 bunches per supply chain scenario were used.

\section{Peel color}

Color was assessed using a colorimeter (Minolta CR-400, Minolta Corp, Osaka, Japan) and expressed as CIE $\mathrm{L}^{*}, \mathrm{a}^{*}, \mathrm{~b}^{*}$ coordinate where $\mathrm{L}^{*}$ defines lightness, $\mathrm{a}^{*}$ denotes the red/green value and $b^{*}$ the yellow/blue value [30]. A total of, 120 berries per supply chain scenario were evaluated for peel color.

\section{Firmness}

Berry firmness $(\mathrm{N})$ was measured by compression (TA.XT.plus, Stable Micro Systems Ltd., Surrey, UK) [31]. In total, 120 berries per supply chain scenario were evaluated for firmness. 


\subsection{Environmental and Economic Impacts of Postharvest Losses}

Total greenhouse gas emissions were calculated using values provided by [32]. That study examined the annual cycle for grape production, beginning with establishment costs, raw material extraction for production of inputs used on the vineyard and included the factors of fertilizer, tillage, irrigation, pest management, electricity and fuel consumption, ending at delivery of grapes. For every ton of grapes produced, stored and transported to the retail market, approximately 0.91 ton of $\mathrm{CO}_{2 \mathrm{eq}}$ is emitted into the atmosphere. The energy cost for producing and marketing the lost produce was obtained using a reference value of $6529 \mathrm{MJ} /$ ton provided by [33], and the water footprint was determined by multiplying the quantity of lost produce with the reference water footprint value of $210.35 \mathrm{~m}^{3}$ /ton provided by [34]. The value of table grapes lost was calculated using values provided by [17], R13134/ton for locally sold produce and R21002/ton for exported produce.

\subsection{Statistical Analysis}

Data on farm losses at harvest were subjected to a one-way analysis of variance (ANOVA) and the physicochemical analysis data for firmness, total soluble solids (TSS), titratable acidity (TA), peel color, weight loss, decay, $\mathrm{SO}_{2}$ damage, and stem browning were subjected to mixed model analysis of variance (ANOVA) using Statistica version 13.2 (TIBCO Software Inc., Palo Alto, CA, USA) with 'farm' and 'time' as fixed effect and cartons as a random effect.

\section{Results}

\subsection{Physical Losses at Farm Level}

In 2017 the measured losses at harvest for individual farms were $7.5 \%, 9.7 \%, 15.7 \%$, and $23.3 \%$ for $\mathrm{V}, \mathrm{K}, \mathrm{R}$, or $\mathrm{D}$, respectively, while in 2018 the same farms lost $6.17 \%, 6.39 \%$, $5.51 \%$, and $5.85 \%$. The average loss in 2017 was $13.9 \%$ and $5.97 \%$ in 2018 . The main reasons for the losses in 2017 were mechanical damage $(7.1 \%)$, poor berry color $(5 \%)$, and decay $(1.8 \%)$. In 2018 the reasons remained the same, although the amounts lost differed with mechanical damage $(3.09 \%)$, poor berry color $(1.77 \%)$, and decay $(1.11 \%)$.

\subsection{Physical Losses along the Simulated Supply Chain}

\subsubsection{Weight Loss, Decay and $\mathrm{SO}_{2}$ Damage}

Supply chain scenario A (handling and marketing fruit under ambient conditions)

There was no statistically significant weight loss $(p=0.28)$ after harvest in 2017 (Table 2); however, there was a decrease in weight of $2.34 \%$ after 3 days, $4.47 \%$ after 7 days and $7.6 \%$ after 10 days, while in 2018 a decrease of $1.55 \%$ was noted after 3 days, $1.83 \%$ after 7 days and $4.43 \%$ after 10 days. $(p=0.19)$. While not statistically significant, this decrease in weight is important in terms of losses as it could affect the profit margin as fruit are sold by weight. The incidence of decay increased significantly $(p<0.01)$ over time from $1 \%$ after 3 days to $3.3 \%$ after 7 days and $7.6 \%$ after 10 days in 2017 and from $0.85 \%$ after 3 days to $1.67 \%$ after 7 days and $2.67 \% 10$ days after harvest in $2018(p<0.01)$. 
Table 2. Physical losses of 'Crimson Seedless' table grapes measured as weight loss (\%) and decayed and $\mathrm{SO}_{2}$ damaged berries (\%) after 3, 7 and 10 days at ambient conditions $\left(25.1 \pm 1.3^{\circ} \mathrm{C}\right.$ and $46.6 \pm 6.0 \% \mathrm{RH}$ ). Mean values with different letter(s) in the same column indicate statistically significant differences $(p<0.05)$.

\begin{tabular}{ccccccc}
\hline Season & \multicolumn{3}{c}{2017} & \multicolumn{2}{c}{2018} \\
\hline Time & $\begin{array}{c}\text { Weight } \\
\text { Loss (\%) }\end{array}$ & Decay (\%) & SO $_{2}$ (\%) & $\begin{array}{c}\text { Weight } \\
\text { Loss (\%) }\end{array}$ & Decay (\%) & $\mathbf{S O}_{\mathbf{2}}$ (\%) \\
\hline Harvest & - & 0 & 0 & - & 0 & 0 \\
3 days & $2.34^{\mathrm{a}}$ & $1.05^{\mathrm{b}}$ & $1.85^{\mathrm{b}}$ & $1.55^{\mathrm{a}}$ & $0.85^{\mathrm{b}}$ & $0.37^{\mathrm{b}}$ \\
7 days & $4.47^{\mathrm{a}}$ & $3.34^{\mathrm{b}}$ & $2.31^{\mathrm{a}}$ & $1.83^{\mathrm{a}}$ & $1.67^{\mathrm{b}}$ & $0.92^{\mathrm{a}}$ \\
10 days & $7.63^{\mathrm{a}}$ & $7.60^{\mathrm{a}}$ & $2.57^{\mathrm{a}}$ & $4.43^{\mathrm{a}}$ & $2.67^{\mathrm{a}}$ & $1.19^{\mathrm{a}}$ \\
p-value $^{\mathrm{a}}$ & 0.28 & $<0.01$ & $<0.01$ & $0.19^{\circ}$ & $<0.01$ & $<0.01$ \\
\hline
\end{tabular}

Note: Mean values within the same column with different letters are significantly $(p<0.05)$ different by Duncan's Multiple Range test (DMRT).

The incidence of $\mathrm{SO}_{2}$ berry damage increased significantly over time from $1.85 \%$ after 3 days to $2.31 \%$ after 7 days and $2.57 \%$ after 10 days in 2017 and from $0.37 \%$ after 3 days to $0.92 \%$ after 7 days and $1.19 \%$ after 10 days in $2018(p<0.01)$.

Supply chain scenario B (to local retail markets)

There was no statistically significant weight loss (Table 3) in both seasons (2017; $p=0.91,2018 ; p=0.99$ ). However, the weight decreased by $1.41 \%$ after 14 days in cold storage, $1.87 \%$ after 10 days at retail conditions, and then by $2.53 \%, 3.78$ and $5.36 \%$ after 3 , 7 and 10 days under ambient conditions, respectively, in 2017. While in 2018, the decrease in weight was $1.85 \%$ after 14 days in cold storage, $2.57 \%$ after 10 days at retail conditions, and then $4.03 \%, 4.40$ and $6.76 \%$ after 3,7 and 10 days under ambient conditions. The incidence of berry decay increased significantly $(p<0.01)$ over time, although it remained at zero for the 14 days duration in cold storage $\left(-0.3 \pm 0.7^{\circ} \mathrm{C}, 81.3 \pm 4.1 \% \mathrm{RH}\right)$ in 2017 with a small incidence of $0.4 \%$ in 2018 . After 10 days at local retail conditions $\left(5.4 \pm 0.6^{\circ} \mathrm{C}\right.$, $83.7 \pm 2.9 \% \mathrm{RH}$ ), there was a decay incidence of $2.1 \%$ in 2017 and $1.2 \%$ in 2018 . After 3 days under ambient conditions $\left(25.1 \pm 1.3{ }^{\circ} \mathrm{C}\right.$ and $\left.46.6 \pm 6.0 \% \mathrm{RH}\right)$, the incidence of decay increased significantly $(p<0.01)$ to $2.5 \%$ in 2017 and $2.2 \%$ in 2018 . After 7 days, this increased to $5.5 \%$ in 2017 and $3.3 \%$ in 2018 , and after 10 days to $8.6 \%$ and $4.7 \%$ in 2017 and 2018, respectively.

Table 3. Physical losses of 'Crimson Seedless' table grapes measured as weight loss (\%) and decayed and $\mathrm{SO}_{2}$ damaged berries (\%) after 14 days cold storage $\left(-0.3 \pm 0.7{ }^{\circ} \mathrm{C}, 81.3 \pm 4.1 \% \mathrm{RH}\right)$, after another 10 days at retail conditions $\left(5.4 \pm 0.6{ }^{\circ} \mathrm{C}, 83.7 \pm 2.9 \% \mathrm{RH}\right)$ and then 3,7 and 10 days at ambient conditions $\left(25.1 \pm 1.3{ }^{\circ} \mathrm{C}\right.$ and $\left.46.6 \pm 6.0 \% \mathrm{RH}\right)$. Mean values with different letter(s) in the same column indicate statistically significant differences $(p<0.05)$.

\begin{tabular}{|c|c|c|c|c|c|c|}
\hline Season & 2017 & & & & 2018 & \\
\hline Time & $\begin{array}{c}\text { Weight } \\
\text { Loss (\%) }\end{array}$ & Decay (\%) & $\mathrm{SO}_{2}(\%)$ & $\begin{array}{l}\text { Weight } \\
\text { Loss (\%) }\end{array}$ & Decay (\%) & $\mathrm{SO}_{2}(\%)$ \\
\hline Harvest & - & 0 & 0 & - & 0 & 0 \\
\hline 14 days $\left(-0.5^{\circ} \mathrm{C}\right)$ & $1.41^{\mathrm{a}}$ & 0 & $1.0^{\mathrm{b}}$ & $1.85^{\mathrm{a}}$ & $0.4^{\mathrm{e}}$ & $0.8^{\mathrm{b}}$ \\
\hline 10 days $\left(5^{\circ} \mathrm{C}\right)$ & $1.87^{\mathrm{a}}$ & $2.1^{c}$ & $1.8^{\mathrm{ab}}$ & $2.57^{\mathrm{a}}$ & $1.2^{\mathrm{d}}$ & $1.7^{\mathrm{ab}}$ \\
\hline 3 days & $2.53^{a}$ & $2.5^{c}$ & $2.1^{\mathrm{a}}$ & $4.03^{\mathrm{a}}$ & $2.2^{\mathrm{c}}$ & $2.1^{\mathrm{a}}$ \\
\hline 7 days & $3.78^{a}$ & $5.5^{b}$ & $2.2^{\mathrm{a}}$ & $4.40^{\mathrm{a}}$ & $3.3^{b}$ & $2.1^{\mathrm{a}}$ \\
\hline 10 days & $5.36^{\mathrm{a}}$ & $8.6^{\mathrm{a}}$ & $2.4^{\mathrm{a}}$ & $6.76^{\mathrm{a}}$ & $4.7^{\mathrm{a}}$ & $2.1^{\mathrm{a}}$ \\
\hline$p$-value & 0.91 & $<0.01$ & 0.02 & 0.99 & $<0.01$ & $<0.01$ \\
\hline
\end{tabular}

Note: Mean values within the same column with different letters are significantly $(p<0.05)$ different by Duncan's Multiple Range test (DMRT).

The incidence of $\mathrm{SO}_{2}$ berry damage in this study was $1 \%$ after 14 days in cold storage in $2017(p=0.02)$ and $0.8 \%$ in $2018(p<0.01) . \mathrm{SO}_{2}$ damage increased significantly after 
10 days at local retail conditions from $1.8 \%$ in 2017 and $1.7 \%$ in 2018 to $2.1 \%$ after 3 days at ambient conditions in both years, after which there was no further significant change.

Supply chain scenario $C$ (to international retail markets)

In 2017, weight decreased by $4.82 \%$ after 28 days in cold storage, $5.50 \%$ after 10 days at retail conditions and $6.61 \%, 7.90 \%$ and $10.22 \%$ after 3,7 and 10 days under ambient conditions, respectively. In 2018, percentage decreases in weight were $1.89 \%$ after 28 days in cold storage, $2.45 \%$ after 10 days at retail conditions and $2.64 \%, 3.95 \%$ and $5.18 \%$ after 3 , 7 and 10 days under ambient conditions, respectively. (Table 4). Percentage decay increased significantly over time $(p<0.01)$. After 28 days in cold storage $\left(-0.3 \pm 0.7^{\circ} \mathrm{C}, 81.3 \pm 4.1 \%\right.$ $\mathrm{RH}$ ), there was a $2.14 \%$ incidence of decay in 2017 and $0.94 \%$ in 2018. After 10 days at retail display conditions $\left(5.4 \pm 0.6^{\circ} \mathrm{C}, 83.7 \pm 2.9 \% \mathrm{RH}\right)$ this increased to $3.2 \%$ in 2017 and $2.6 \%$ in 2018. After being moved to ambient temperature and humidity conditions $\left(25.1 \pm 1.3^{\circ} \mathrm{C}\right.$ and $46.6 \pm 6.0 \% \mathrm{RH}$ ) for 3 days, decay increased to $4.44 \%$ in 2017 and $3.16 \%$ in 2018 . After 7 days, decay increased to $6.53 \%$ in 2017 and $4.95 \%$ in 2018, and after 10 days, it reached $9.92 \%$ in 2017 and $8.30 \%$ in 2018. $\mathrm{SO}_{2}$ damage remained low. After 28 days in cold storage plus 10 days at retail conditions, less than $0.5 \%$ damage was visible. In 2017 it increased significantly $(p<0.01)$ after removal from cold storage to $1.39 \%$ after 3 days at ambient conditions, $1.68 \%$ after 7 days and $1.85 \%$ after 10 days, but remained below $2 \%$ overall. In 2018, however, it did not increase significantly $(p=0.26)$ over time and remained below $1 \%$ overall.

Table 4. Physical losses of 'Crimson Seedless' table grapes measured as weight loss (\%), decayed and $\mathrm{SO}_{2}$ damaged berries (\%) after 28 days cold storage $\left(-0.3 \pm 0.7^{\circ} \mathrm{C}, 81.3 \pm 4.1 \% \mathrm{RH}\right)$, after another 10 days at retail conditions $\left(5.4 \pm 0.6^{\circ} \mathrm{C}, 83.7 \pm 2.9 \% \mathrm{RH}\right)$ and then for 3,7 and 10 days at ambient conditions $\left(25.1 \pm 1.3^{\circ} \mathrm{C}\right.$ and $\left.46.6 \pm 6.0 \% \mathrm{RH}\right)$. Mean values with different letter(s) in the same column indicate statistically significant differences $(p<0.05)$.

\begin{tabular}{|c|c|c|c|c|c|c|}
\hline \multirow{2}{*}{$\begin{array}{c}\text { Season } \\
\text { Time }\end{array}$} & \multicolumn{3}{|c|}{2017} & \multicolumn{3}{|c|}{2018} \\
\hline & $\begin{array}{l}\text { Weight } \\
\text { Loss (\%) }\end{array}$ & Decay (\%) & $\mathrm{SO}_{2}(\%)$ & $\begin{array}{l}\text { Weight } \\
\text { Loss (\%) }\end{array}$ & Decay (\%) & $\mathrm{SO}_{2}(\%)$ \\
\hline Harvest & - & 0 & 0 & - & 0 & 0 \\
\hline $\begin{array}{c}28 \text { days } \\
\left(-0.5^{\circ} \mathrm{C}\right)\end{array}$ & $4.82^{\mathrm{a}}$ & $2.14^{\mathrm{d}}$ & $0.47^{\mathrm{c}}$ & 1.89 & $0.94^{\mathrm{d}}$ & $0.25^{\mathrm{a}}$ \\
\hline $\begin{array}{c}10 \text { days } \\
\left(5^{\circ} \mathrm{C}\right)\end{array}$ & $5.50^{\mathrm{a}}$ & $3.20^{\mathrm{cd}}$ & $0.94^{c}$ & 2.45 & $2.60^{c}$ & $0.62^{\mathrm{a}}$ \\
\hline 3 days & $6.61^{\mathrm{a}}$ & $4.44^{\mathrm{c}}$ & $1.39^{b}$ & 2.64 & $3.16^{c}$ & $0.62^{\mathrm{a}}$ \\
\hline 7 days & $7.90^{\mathrm{a}}$ & $6.53^{b}$ & $1.68^{a b}$ & 3.95 & $4.95^{b}$ & $0.62^{a}$ \\
\hline 10 days & $10.22^{a}$ & $9.92^{\mathrm{a}}$ & $1.85^{\mathrm{a}}$ & 5.18 & $8.30^{\mathrm{a}}$ & $0.62^{a}$ \\
\hline$p$-value & 0.85 & $<0.01$ & $<0.01$ & 0.84 & $<0.01$ & 0.26 \\
\hline
\end{tabular}

Note: Mean values within the same column with different letters are significantly $(p<0.05)$ different by Duncan's Multiple Range test (DMRT).

Supply chain scenario D (simulated 'abusive' treatment of fruit within the export chain)

There was no statistically significant difference in bunch weight over time $(p=0.19)$, although a $1.35 \%$ decrease in weight is noted after 28 days in cold storage, $2.17 \%$ after 2 days at 'abusive' ambient conditions, 3.04\% after 10 days at retail conditions and 3.96\%, $4.74 \%$ and $5.70 \%$ after 3,7 and 10 days under ambient conditions, respectively (Table 5 ). Percentage decay increased significantly over time $(p<0.01)$. After 28 days in cold storage, there was a $0.84 \%$ incidence of decay, increasing to $1.34 \%$ after breaking the cold chain with 2 days at 'abusive' ambient conditions, 10 days at retail conditions increased this to $2.35 \%$, and decay kept increasing significantly at ambient conditions to $3.24 \%$ after 3 days, $4.46 \%$ after 7 days and $6.7 \%$ after 10 days. $\mathrm{SO}_{2}$ damage remained low, with only $0.88 \%$ visible after 28 days in cold storage and did not increase significantly $(p=0.99)$ over time, remaining around $1 \%$. 
Table 5. Physical losses of 'Crimson Seedless' table grapes measured as weight loss (\%), decayed and $\mathrm{SO}_{2}$ damaged berries (\%) after 28 days cold storage $\left(-0.3 \pm 0.7^{\circ} \mathrm{C}, 81.3 \pm 4.1 \% \mathrm{RH}\right), 2$ days 'abusive' temperature and humidity $\left(25.1 \pm 1.3^{\circ} \mathrm{C}\right.$ and $\left.46.6 \pm 6.0 \% \mathrm{RH}\right)$, another 10 days at retail conditions $\left(5.4 \pm 0.6{ }^{\circ} \mathrm{C}, 83.7 \pm 2.9 \% \mathrm{RH}\right)$ and then for 3,7 and 10 days at ambient conditions $\left(25.1 \pm 1.3{ }^{\circ} \mathrm{C}\right.$ and $46.6 \pm 6.0 \% \mathrm{RH})$. Mean values with different letter(s) in the same column indicate statistically significant differences $(p<0.05)$.

\begin{tabular}{cccc}
\hline \multicolumn{2}{c}{ Season } & & 2018 \\
\hline Time & Weight Loss (\%) & Decay (\%) & $\mathbf{S O}_{\mathbf{2}} \mathbf{( \% )}$ \\
\hline Harvest & - & 0 & 0 \\
28 days $\left(-0.5^{\circ} \mathrm{C}\right)$ & $1.31^{\mathrm{a}}$ & $0.84^{\mathrm{e}}$ & $0.88^{\mathrm{a}}$ \\
2 days $($ ambient $)$ & $2.17^{\mathrm{a}}$ & $1.33^{\mathrm{e}}$ & $0.98^{\mathrm{a}}$ \\
10 days $\left(5^{\circ} \mathrm{C}\right)$ & $3.04^{\mathrm{a}}$ & $2.35^{\mathrm{d}}$ & $1.06^{\mathrm{a}}$ \\
3 days & $3.96^{\mathrm{a}}$ & $3.24^{\mathrm{c}}$ & $1.09^{\mathrm{a}}$ \\
7 days & $4.74^{\mathrm{a}}$ & $4.46^{\mathrm{b}}$ & $1.10^{\mathrm{a}}$ \\
10 days & $5.70^{\mathrm{a}}$ & $6.70^{\mathrm{a}}$ & $1.21^{\mathrm{a}}$ \\
$p$-value & $0.19^{\mathrm{a}}$ & $<0.01$ & 0.99 \\
\hline
\end{tabular}

Note: Mean values within the same column with different letters are significantly $(p<0.05)$ different by Duncan's Multiple Range test (DMRT).

\subsubsection{Total Amount of Physical Losses}

When the amount of weight loss, decay and $\mathrm{SO}_{2}$ damage are combined, the total amount of losses along the different supply chain scenarios are as follows (Figures 1 and 2):

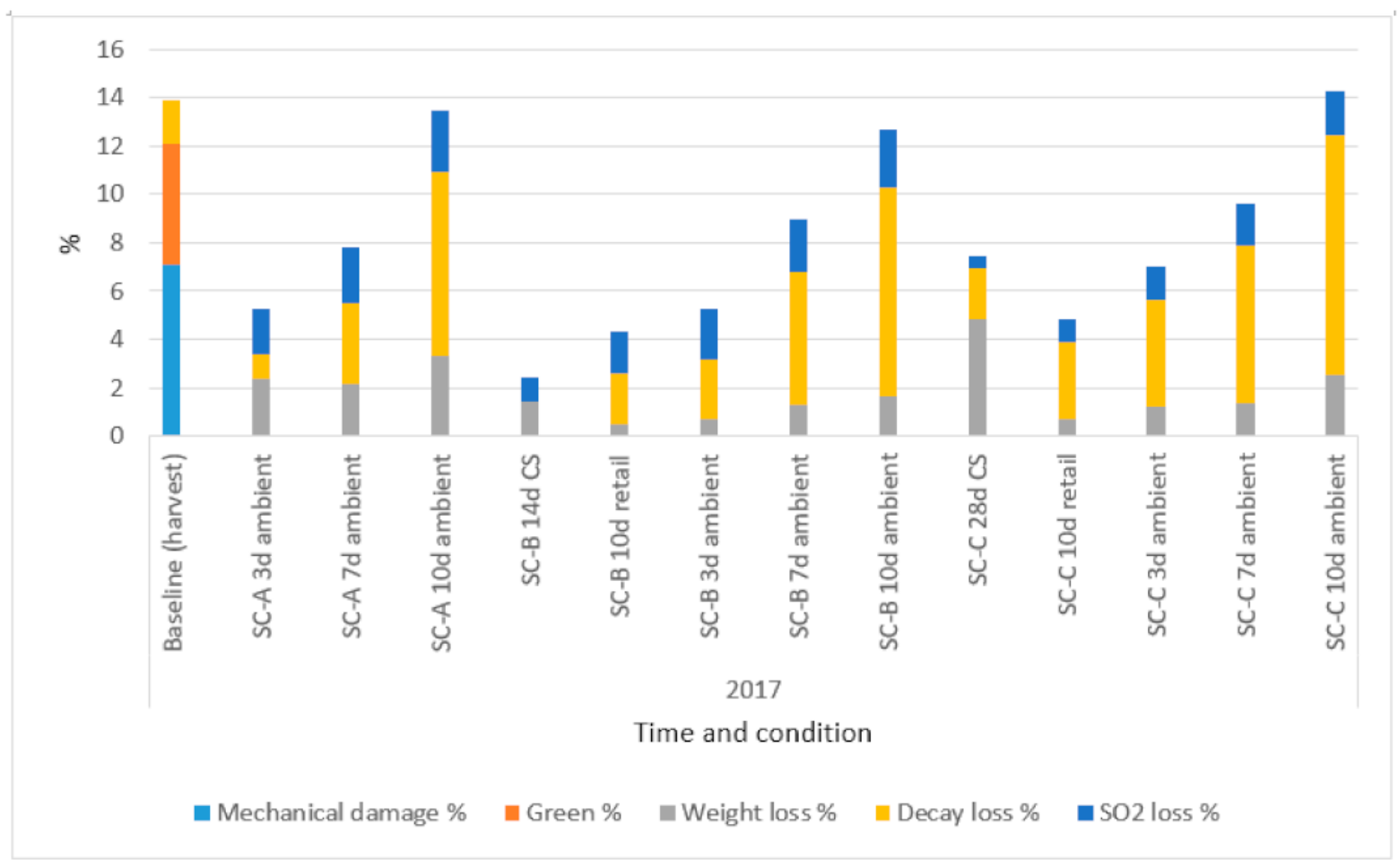

Figure 1. Total physical losses of grape 'Crimson Seedless' at harvest 2017 along different supply chain (SC) scenarios where SC-A represents marketing at ambient conditions, SC-B represents the supply chain to the local retail market, SC-C represents the international supply chain, and SC-D represents the international supply chain including 2 days 'abusive' ambient temperature and humidity. 


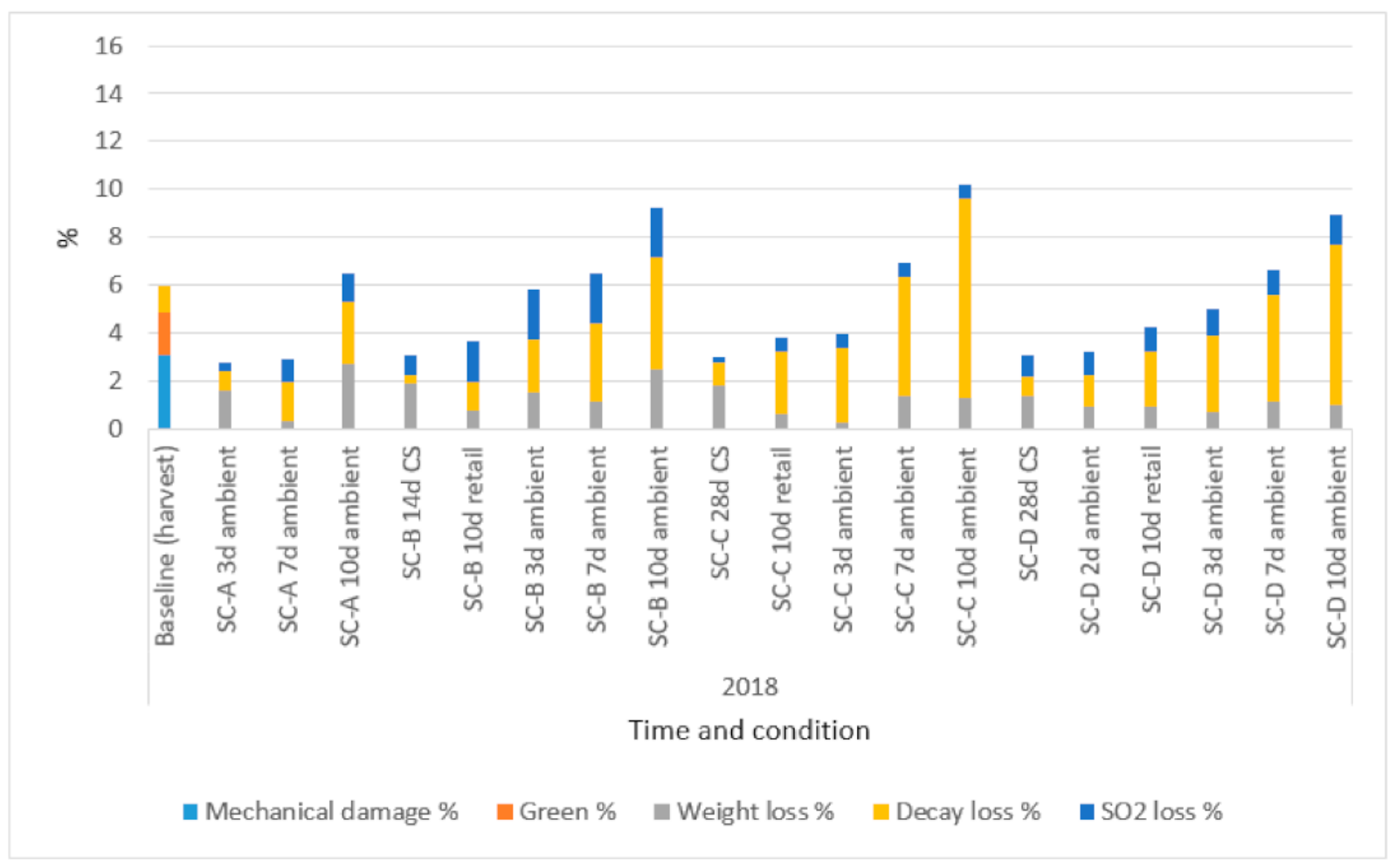

Figure 2. Total physical losses of grape 'Crimson Seedless' at harvest 2018 along different supply chain (SC) scenarios where SC-A represents marketing at ambient conditions, SC-B represents the supply chain to the local retail market, SC-C represents the international supply chain, and SC-D represents the international supply chain including 2 days 'abusive' ambient temperature and humidity.

Supply chain scenario A (marketing at ambient conditions)

In $2017,13.9 \%$ was lost at harvest, followed by $5.25 \%$ after 3 days, $7.83 \%$ after 7 days, and $13.47 \%$ after 10 days. The total losses were $27.37 \%$. In 2018 only $5.97 \%$ were lost at harvest, $2.77 \%$ after 3 days, $2.87 \%$ after 7 days and $6.51 \%$ after 10 days. The total losses were $12.48 \%$, less than half that of the previous season.

Supply chain scenario B (to local retail markets)

After 14 days in cold storage in 2017, 2.41\% were lost, $4.36 \%$ after 10 days at retail condition followed by an additional $5.27 \%$ after 3 days at ambient conditions (shelf-life), $8.98 \%$ after 7 days, and $12.64 \%$ after 10 days. When this is added to the initial $13.9 \%$ lost at harvest, the total for this supply chain simulation is $26.54 \%$. In $2018,3.05 \%$ were lost after 14 days in cold storage, $3.65 \%$ after 10 days under retail conditions, $5.80 \%$ after 3 days under ambient conditions and remained thus after 7 days while increasing again to $10.22 \%$ after 10 days. The total loss along this simulated supply chain in 2018 was $16.19 \%$.

Supply chain scenario C (to international markets)

In 2017, 7.41\% were lost after 28 days in cold storage, another $4.36 \%$ after 10 days under retail conditions and a further $7.03 \%$ after 3 days under ambient conditions, $9.59 \%$ after 7 days and $14.29 \%$ after 10 days. A total of $28.19 \%$ was lost in this export supply chain simulation in 2017. In 2018, 2.99\% were lost after 28 days in cold storage, $3.79 \%$ after 10 days under retail conditions, $3.97 \%$ after 3 days under ambient conditions, $6.92 \%$ after 7 days, and $10.22 \%$ after 10 days. A total of $16.99 \%$ were lost in 2018 .

Supply chain scenario D (simulated 'abusive' storage conditions of fruit within the international supply chain)

This simulation was done during the 2018 season only. It was found that $3.03 \%$ was lost after 28 days in cold storage, 3.19\% after 2 days of 'abusive' ambient condition, $4.27 \%$ after 10 days at retail conditions. After 3 days under ambient condition losses increased to $5 \%, 6.66 \%$ after 7 days, and $8.91 \%$ after 10 days. 


\subsection{Quality Losses along the Supply Chain}

Supply chain scenario A (marketing at ambient conditions)

In the 2017 season, the berry color became lighter (L) over time, (Table 6) although the change was just not statistically significant $(p=0.06)$, during the 2018 season (Table 7), however, the change in lightness (L) of berry color became statistically significant $(p<0.01)$. The measurements for $\mathrm{a}^{*}$ denoting the red/green values $(p=0.45)$ and $\mathrm{b}^{*}$ indicating the yellow/blue values $(p=0.98)$ in 2017 and $\mathrm{a}^{*}(p=0.21)$ and $\mathrm{b}^{*}(p=0.75)$ in 2018, did not change significantly. There was no significant difference in firmness in 2017 or 2018 $(p=0.79)$, although the values decreased over time. The TSS $(p=0.85)$ and TA $(p=0.50)$ values did not change significantly in 2017 or in 2018, TSS $(p=0.75)$ and TA $(p=0.73)$. For both seasons, the stem color changed from fresh and green to mostly dry and brown within 7 days after harvest $(p<0.01)$.

Table 6. Supply chain scenario A (2017): changes in quality attributes of color $\left(\mathrm{L}, \mathrm{a}^{*}\right.$ and $\left.\mathrm{b}^{*}\right)$, firmness (N), total soluble solids (TSS) (Brix $\left.{ }^{\circ}\right)$, titratable acidity (TA) $(\%)$, and stem browning index for 'Crimson Seedless' table grapes at harvest and after 3, 7 and 10 days at ambient conditions $\left(25.1 \pm 1.3{ }^{\circ} \mathrm{C}\right.$ and $\left.46.6 \pm 6.0 \% \mathrm{RH}\right)$. Mean values with different letter(s) in the same column indicate statistically significant differences $(p<0.05)$.

\begin{tabular}{cccccccc}
\hline \multicolumn{2}{c}{ Year } & & & \multicolumn{3}{c}{2017} \\
\hline Time & $\mathbf{L}$ & $\mathbf{a}^{*}$ & $\mathbf{b}^{*}$ & $\begin{array}{c}\text { Firmness } \\
\mathbf{( N )}\end{array}$ & $\begin{array}{c}\text { TSS } \\
\left(\mathbf{B r i x}^{\circ}\right)\end{array}$ & $\begin{array}{c}\text { TA } \\
\mathbf{( \% )}\end{array}$ & $\begin{array}{c}\text { Stem Browning } \\
\text { Index }\end{array}$ \\
\hline Harvest & $29.55^{\mathrm{a}}$ & $5.85^{\mathrm{a}}$ & $6.77^{\mathrm{a}}$ & $98.22^{\mathrm{a}}$ & $18.72^{\mathrm{a}}$ & $0.89^{\mathrm{a}}$ & $1^{\mathrm{d}}$ \\
3 days & $30.81^{\mathrm{a}}$ & $4.98^{\mathrm{a}}$ & $6.56^{\mathrm{a}}$ & $97.80^{\mathrm{a}}$ & $18.16^{\mathrm{a}}$ & $0.75^{\mathrm{a}}$ & $2.4^{\mathrm{c}}$ \\
7 days & $31.07^{\mathrm{a}}$ & $5.08^{\mathrm{a}}$ & $6.59^{\mathrm{a}}$ & $96.87^{\mathrm{a}}$ & $18.34^{\mathrm{a}}$ & $0.73^{\mathrm{a}}$ & $4.4^{\mathrm{b}}$ \\
10 days & $30.91^{\mathrm{a}}$ & $4.88^{\mathrm{a}}$ & $6.75^{\mathrm{a}}$ & $95.47^{\mathrm{a}}$ & $19.15^{\mathrm{a}}$ & $0.80^{\mathrm{a}}$ & $5.0^{\mathrm{a}}$ \\
$p$-value & 0.06 & 0.45 & 0.98 & 0.79 & 0.85 & 0.50 & $<0.01$ \\
\hline
\end{tabular}

Note: Mean values within the same column with different letters are significantly $(p<0.05)$ different by Duncan's Multiple Range test (DMRT).

Table 7. Supply chain scenario A (2018): changes in quality attributes of color $\left(L, a^{*}\right.$ and $\left.b^{*}\right)$, firmness $(\mathrm{N})$, TSS $\left(\right.$ Brix $\left.^{\circ}\right)$, TA $(\%)$, and stem browning index for 'Crimson Seedless' table grapes at harvest and after 3,7 and 10 days at ambient conditions $\left(25.1 \pm 1.3^{\circ} \mathrm{C}\right.$ and $\left.46.6 \pm 6.0 \% \mathrm{RH}\right)$. Mean values with different letter(s) in the same column indicate statistically significant differences $(p<0.05)$.

\begin{tabular}{|c|c|c|c|c|c|c|c|}
\hline \multicolumn{4}{|c|}{ Year } & \multicolumn{4}{|c|}{2018} \\
\hline Time & L & $a^{*}$ & $\mathbf{b}^{*}$ & $\begin{array}{l}\text { Firmness } \\
\text { (N) }\end{array}$ & $\begin{array}{c}\text { TSS } \\
\left(\text { Brix }^{\circ}\right)\end{array}$ & $\begin{array}{l}\text { TA } \\
(\%)\end{array}$ & $\begin{array}{c}\text { Stem Browning } \\
\text { Index }\end{array}$ \\
\hline Harvest & $27.46^{c}$ & $7.91^{a}$ & $6.95^{a}$ & $98.15^{a}$ & $20.88^{a}$ & $0.86^{\mathrm{a}}$ & $1^{\mathrm{c}}$ \\
\hline 3 days & $27.64^{b c}$ & $6.80^{\mathrm{a}}$ & $6.74^{\mathrm{a}}$ & $97.73^{a}$ & $16.77^{a}$ & $0.76^{\mathrm{a}}$ & $2.5^{b}$ \\
\hline 7 days & $27.96^{b}$ & $6.84^{\mathrm{a}}$ & $6.83^{a}$ & $96.96^{a}$ & $18.60^{a}$ & $0.79^{a}$ & $4.6^{\mathrm{a}}$ \\
\hline 10 days & $28.94^{\mathrm{a}}$ & $7.85^{\mathrm{a}}$ & $7.00^{\mathrm{a}}$ & $95.55^{\mathrm{a}}$ & $19.15^{a}$ & $0.85^{\mathrm{a}}$ & $4.8^{\mathrm{a}}$ \\
\hline$p$-value & 0.06 & 0.45 & 0.98 & 0.79 & 0.85 & 0.50 & $<0.01$ \\
\hline
\end{tabular}

Note: Mean values within the same column with different letters are significantly $(p<0.05)$ different by Duncan's Multiple Range test (DMRT).

Supply chain scenario B (to local retail markets)

In 2017, there were no significant changes in any color attributes for lightness (L) denoting black/white values $(p=0.79)$, $\mathrm{a}^{*}$ denoting the red/green values $(p=0.49)$ or $\mathrm{b}^{*}$ indicating the yellow/blue values $(p=0.25)$ (Table 8$)$. In 2018, no significant differences were measured for $\mathrm{a}^{*}(p=0.31)$ and $\mathrm{b}^{*}(p=0.19)$. However, lightness (L) values increased $(p<0.01)$, although this only became significant after 10 days at ambient conditions as there was no significant difference between baseline measurements, 14 days in cold storage, 10 days at retail conditions, or even after a week at ambient temperature and humidity (Table 9). Berry firmness $(p=0.21)$ in 2017 and $(p=0.49)$ in 2018, showed no statistically 
significant changes. While TA $(p=0.27)$ and TSS $(p=0.73)$ showed no significant changes in 2017, in 2018 the values did indicate an increase for both TA $(p<0.01)$ and TSS $(p<0.01)$ over the storage period. For both seasons, bunch stems and rachi remained fresh and green during the 14 days in cold storage $\left(-0.3 \pm 0.7^{\circ} \mathrm{C}, 81.3 \pm 4.1 \% \mathrm{RH}\right)$, but changed significantly $(p<0.01)$ during 10 days at retail display conditions $\left(5.4 \pm 0.6{ }^{\circ} \mathrm{C}, 83.7 \pm 2.9 \%\right.$ $\mathrm{RH})$, and after 7 days storage under ambient conditions $\left(25.1 \pm 1.3^{\circ} \mathrm{C}\right.$ and $46.6 \pm 6.0 \%$ $\mathrm{RH})$, the stems were mostly dry and brown.

Table 8. Supply chain scenario B (2017): changes in quality attributes of color ( $\mathrm{L}, \mathrm{a}^{*}$ and $\left.\mathrm{b}^{*}\right)$, firmness $(\mathrm{N})$, TSS (Brix $\left.{ }^{\circ}\right)$, TA $(\%)$, and stem browning index for 'Crimson Seedless' table grapes at harvest after 14 days cold storage $\left(-0.3 \pm 0.7^{\circ} \mathrm{C}, 81.3 \pm 4.1 \% \mathrm{RH}\right)$, after another 10 days at retail conditions $\left(5.4 \pm 0.6{ }^{\circ} \mathrm{C}, 83.7 \pm 2.9 \% \mathrm{RH}\right)$ and then for 3,7 and 10 days at ambient conditions $\left(25.1 \pm 1.3{ }^{\circ} \mathrm{C}\right.$ and $46.6 \pm 6.0 \% \mathrm{RH})$. Mean values with different letter(s) in the same column indicate statistically significant differences $(p<0.05)$.

\begin{tabular}{|c|c|c|c|c|c|c|c|}
\hline \multicolumn{8}{|c|}{2017} \\
\hline Time & $\mathbf{L}$ & $a^{*}$ & $\mathbf{b}^{*}$ & $\begin{array}{l}\text { Firmness } \\
(\mathrm{N})\end{array}$ & $\begin{array}{c}\text { TSS } \\
\left(\text { Brix }^{\circ}\right)\end{array}$ & $\begin{array}{l}\text { TA } \\
(\%)\end{array}$ & $\begin{array}{c}\text { Stem Browning } \\
\text { Index }\end{array}$ \\
\hline Harvest & $33.65^{a}$ & $7.76^{a}$ & $7.28^{a}$ & $98.23^{a}$ & $17.34^{\mathrm{a}}$ & $0.99^{a}$ & $1^{d}$ \\
\hline $\begin{array}{l}14 \text { days } \\
\left(-0.5^{\circ} \mathrm{C}\right)\end{array}$ & $30.78^{a}$ & $6.60^{\mathrm{a}}$ & $7.08^{a}$ & $\begin{array}{c}100.14 \\
\mathrm{a}\end{array}$ & $19.39^{a}$ & $0.91^{\mathrm{a}}$ & $1.4^{\mathrm{d}}$ \\
\hline $\begin{array}{l}10 \text { days } \\
\left(5^{\circ} \mathrm{C}\right)\end{array}$ & $29.78^{a}$ & $7.64^{a}$ & $7.74^{\mathrm{a}}$ & $\begin{array}{c}106.59 \\
\mathrm{a}\end{array}$ & $18.97^{\mathrm{a}}$ & $0.75^{a}$ & $2.4^{\mathrm{c}}$ \\
\hline 3 days & $30.61^{a}$ & $6.11^{a}$ & $7.41^{a}$ & $92.02^{a}$ & $19.63^{a}$ & $0.77^{a}$ & $3.5^{b}$ \\
\hline 7 days & $30.52^{a}$ & $6.70^{a}$ & $8.44^{\mathrm{a}}$ & $87.59^{\text {a }}$ & $19.52^{\mathrm{a}}$ & $0.70^{a}$ & $4.7^{\mathrm{a}}$ \\
\hline 10 days & $31.38^{\mathrm{a}}$ & $6.86^{a}$ & $9.20^{a}$ & $88.88^{a}$ & $17.10^{\mathrm{a}}$ & $0.68^{a}$ & $4.9^{\mathrm{a}}$ \\
\hline$p$-value & 0.79 & 0.49 & 0.24 & 0.21 & 0.73 & 0.27 & $<0.01$ \\
\hline
\end{tabular}

Note: Mean values within the same column with different letters are significantly $(p<0.05)$ different by Duncan's Multiple Range test (DMRT).

Table 9. Supply chain scenario B (2018): changes in quality attributes of color $\left(L, a^{*}\right.$ and $\left.b^{*}\right)$, firmness $(\mathrm{N})$, TSS (Brix $\left.{ }^{\circ}\right)$, TA $(\%)$, and stem browning index for 'Crimson Seedless' table grapes at harvest after 14 days cold storage $\left(-0.3 \pm 0.7^{\circ} \mathrm{C}, 81.3 \pm 4.1 \% \mathrm{RH}\right)$, after another 10 days at retail conditions $\left(5.4 \pm 0.6{ }^{\circ} \mathrm{C}, 83.7 \pm 2.9 \% \mathrm{RH}\right)$ and then for 3,7 and 10 days at ambient conditions $\left(25.1 \pm 1.3^{\circ} \mathrm{C}\right.$ and $46.6 \pm 6.0 \% \mathrm{RH})$. Mean values with different letter(s) in the same column indicate statistically significant differences $(p<0.05)$.

\begin{tabular}{|c|c|c|c|c|c|c|c|}
\hline \multicolumn{8}{|c|}{2018} \\
\hline Time & $\mathbf{L}$ & $a^{*}$ & $\mathbf{b}^{*}$ & $\begin{array}{l}\text { Firmness } \\
(\mathrm{N})\end{array}$ & $\begin{array}{c}\text { TSS } \\
\left(\text { Brix }^{\circ}\right)\end{array}$ & $\begin{array}{l}\text { TA } \\
(\%)\end{array}$ & $\begin{array}{c}\text { Stem Browning } \\
\text { Index }\end{array}$ \\
\hline Harvest & $27.46^{b}$ & $7.91^{\mathrm{a}}$ & $2.23^{a}$ & $111.06^{\mathrm{a}}$ & $17.84^{b}$ & $0.72^{c}$ & $1^{d}$ \\
\hline $\begin{array}{l}14 \text { days } \\
\left(-0.5^{\circ} \mathrm{C}\right)\end{array}$ & $27.88^{b}$ & $8.22^{\mathrm{a}}$ & $2.87^{\mathrm{a}}$ & $114.59^{a}$ & $17.99^{b}$ & $0.85^{\mathrm{b}}$ & $1.3^{\mathrm{d}}$ \\
\hline $\begin{array}{l}10 \text { days } \\
\left(5^{\circ} \mathrm{C}\right)\end{array}$ & $27.32^{b}$ & $7.32^{\mathrm{a}}$ & $4.05^{\mathrm{a}}$ & $121.69^{a}$ & $19.14^{\mathrm{a}}$ & $0.82^{b}$ & $2.7^{c}$ \\
\hline 3 days & $27.84^{b}$ & $7.05^{\mathrm{a}}$ & $2.19^{a}$ & $115.23^{a}$ & $18.95^{a}$ & $0.78^{c}$ & $3.7^{b}$ \\
\hline 7 days & $27.56^{b}$ & $6.56^{\mathrm{a}}$ & $1.94^{\mathrm{a}}$ & $119.03^{a}$ & $19.13^{a}$ & $0.89^{a}$ & $4.6^{\mathrm{a}}$ \\
\hline 10 days & $30.30^{a}$ & $6.01^{\mathrm{a}}$ & $3.45^{\mathrm{a}}$ & $120.27^{a}$ & $18.95^{\mathrm{a}}$ & $0.85^{b}$ & $4.8^{\mathrm{a}}$ \\
\hline$p$-value & $<0.01$ & 0.31 & 0.19 & 0.49 & $<0.01$ & $<0.01$ & $<0.01$ \\
\hline
\end{tabular}

Note: Mean values within the same column with different letters are significantly $(p<0.05)$ different by Duncan's Multiple Range test (DMRT).

Supply chain scenario C (to international retail markets)

No significant difference in any color attributes (Table 10) was observed in 2017, L $(p=0.12), \mathrm{a}^{*}(p=0.15)$ and $\mathrm{b}^{*}(p=0.72)$. In 2018, however, the attribute for lightness (L) changed significantly $(p<0.01)$, with berries becoming a bit lighter after removal from 
cold storage but darkening again after 7 days under ambient conditions (Table 11), while $\mathrm{a}^{*}(p=0.26)$ and $\mathrm{b}^{*}(p=0.22)$ remained the same. The average berry firmness remained unchanged in $2017(p=0.90)$ and in $2018(p=0.11)$. No changes were observed in TSS in $2017(p=0.67)$ or in $2018(p=0.30)$. There is a trend, however, indicating that TA may decrease somewhat over time, but with a $p$-value of 0.06 , it was just not statistically significant in 2017, while it was significant in $2018(p<0.01)$. Stem color exhibited the same pattern for both years, remaining mostly fresh and green during the 28 days cold storage $\left(-0.3 \pm 0.7^{\circ} \mathrm{C}, 81.3 \pm 4.1 \% \mathrm{RH}\right)$ only changing significantly $(p<0.01)$ during the 10 days at retail display conditions $\left(5.4 \pm 0.6^{\circ} \mathrm{C}, 83.7 \pm 2.9 \% \mathrm{RH}\right)$ to mostly green with some smaller stems that have turned brown. After 3 days at ambient temperature and humidity $\left(25.1 \pm 1.3{ }^{\circ} \mathrm{C}\right.$ and $\left.46.6 \pm 6.0 \% \mathrm{RH}\right)$, most of the smaller stems (rachi) are brown, but the main stem is still green, after 7 days, however, most stems are dry and brown.

Table 10. Supply chain scenario $C$ (2017): changes in quality attributes of color $\left(\mathrm{L}, \mathrm{a}^{*}\right.$ and $\left.\mathrm{b}^{*}\right)$, firmness $(\mathrm{N})$, TSS $\left(\right.$ Brix $\left.^{\circ}\right)$, TA $(\%)$, and stem browning index for 'Crimson Seedless' table grapes at harvest after 28 days cold storage $\left(-0.3 \pm 0.7^{\circ} \mathrm{C}, 81.3 \pm 4.1 \% \mathrm{RH}\right)$, after another 10 days at retail conditions $\left(5.4 \pm 0.6{ }^{\circ} \mathrm{C}, 83.7 \pm 2.9 \% \mathrm{RH}\right)$ and then for 3,7 and 10 days at ambient conditions $\left(25.1 \pm 1.3^{\circ} \mathrm{C}\right.$ and $46.6 \pm 6.0 \% \mathrm{RH})$. Mean values with different letter(s) in the same column indicate statistically significant differences $(p<0.05)$.

\begin{tabular}{|c|c|c|c|c|c|c|c|}
\hline \multicolumn{8}{|c|}{2017} \\
\hline Time & $\mathbf{L}^{*}$ & $a^{*}$ & $\mathbf{b}^{*}$ & $\begin{array}{l}\text { Firmness } \\
(\mathrm{N})\end{array}$ & $\begin{array}{c}\text { TSS } \\
\left(\text { Brix }^{\circ}\right)\end{array}$ & $\begin{array}{l}\text { TA } \\
(\%)\end{array}$ & $\begin{array}{c}\text { Stem Browning } \\
\text { Index }\end{array}$ \\
\hline Harvest & $30.04^{a}$ & $10.37^{a}$ & $9.36^{a}$ & $98.69^{a}$ & $17.80^{a}$ & $1.13^{a}$ & $1^{\mathrm{e}}$ \\
\hline $\begin{array}{l}28 \text { days } \\
\left(-0.5^{\circ} \mathrm{C}\right)\end{array}$ & $29.94^{\mathrm{a}}$ & $8.80^{a}$ & $9.16^{\mathrm{a}}$ & $94.41^{\mathrm{a}}$ & $18.56^{\mathrm{a}}$ & $0.74^{\mathrm{a}}$ & $1.14^{\mathrm{e}}$ \\
\hline $\begin{array}{l}10 \text { days } \\
\left(5^{\circ} \mathrm{C}\right)\end{array}$ & $28.61^{a}$ & $7.89^{a}$ & $9.54^{\mathrm{a}}$ & $98.70^{a}$ & $19.15^{\mathrm{a}}$ & $0.64^{a}$ & $1.97^{\mathrm{d}}$ \\
\hline 3 days & $31.41^{\mathrm{a}}$ & $6.81^{\mathrm{a}}$ & $8.72^{a}$ & $97.00^{\mathrm{a}}$ & $19.28^{a}$ & $0.73^{a}$ & $3.08^{c}$ \\
\hline 7 days & $31.78^{\mathrm{a}}$ & $6.52^{\mathrm{a}}$ & $8.10^{\mathrm{a}}$ & $99.70^{\mathrm{a}}$ & $19.17^{\mathrm{a}}$ & $0.67^{a}$ & $4.53^{b}$ \\
\hline 10 days & $31.69^{\mathrm{a}}$ & $5.76^{\mathrm{a}}$ & $8.10^{a}$ & $97.20^{a}$ & $18.57^{\mathrm{a}}$ & $0.67^{a}$ & $5.00^{\mathrm{a}}$ \\
\hline$p$-value & 0.12 & 0.15 & 0.72 & 0.90 & 0.67 & 0.06 & $<0.01$ \\
\hline
\end{tabular}

Note: Mean values within the same column with different letters are significantly $(p<0.05)$ different by Duncan's Multiple Range test (DMRT).

Table 11. Supply chain scenario $C$ (2018): changes in quality attributes of color $\left(\mathrm{L}, \mathrm{a}^{*}\right.$ and $\left.\mathrm{b}^{*}\right)$, firmness $(\mathrm{N})$, TSS $\left(\right.$ Brix $\left.^{\circ}\right)$, TA $(\%)$, and stem browning index for 'Crimson Seedless' table grapes at harvest after 28 days cold storage $\left(-0.3 \pm 0.7^{\circ} \mathrm{C}, 81.3 \pm 4.1 \% \mathrm{RH}\right)$, after another 10 days at retail conditions $\left(5.4 \pm 0.6{ }^{\circ} \mathrm{C}, 83.7 \pm 2.9 \% \mathrm{RH}\right)$ and then for 3,7 and 10 days at ambient conditions $\left(25.1 \pm 1.3^{\circ} \mathrm{C}\right.$ and $46.6 \pm 6.0 \% \mathrm{RH})$. Mean values with different letter(s) in the same column indicate statistically significant differences $(p<0.05)$.

\begin{tabular}{|c|c|c|c|c|c|c|c|}
\hline \multicolumn{8}{|c|}{2018} \\
\hline Time & $\mathbf{L}^{*}$ & $a^{*}$ & $\mathbf{b}^{*}$ & $\begin{array}{l}\text { Firmness } \\
\text { (N) }\end{array}$ & $\begin{array}{c}\text { TSS } \\
\left(\text { Brix }^{\circ}\right)\end{array}$ & $\begin{array}{l}\text { TA } \\
(\%)\end{array}$ & $\begin{array}{c}\text { Stem Browning } \\
\text { Index }\end{array}$ \\
\hline Harvest & $27.45^{b}$ & $7.91^{\mathrm{a}}$ & $2.23^{a}$ & $106.60^{a}$ & $17.80^{\mathrm{a}}$ & $0.72^{b}$ & $1^{\mathrm{e}}$ \\
\hline $\begin{array}{l}28 \text { days } \\
\left(-0.5^{\circ} \mathrm{C}\right)\end{array}$ & $27.75^{b}$ & $7.06^{\mathrm{a}}$ & $1.76^{\mathrm{a}}$ & $106.02^{\mathrm{a}}$ & $18.69^{a}$ & $0.77^{\mathrm{a}}$ & $1.97^{\mathrm{e}}$ \\
\hline $\begin{array}{l}10 \text { days } \\
\left(5^{\circ} \mathrm{C}\right)\end{array}$ & $28.09^{a b}$ & $7.20^{\mathrm{a}}$ & $2.47^{\mathrm{a}}$ & $104.34^{\mathrm{a}}$ & $18.58^{a}$ & $0.77^{\mathrm{a}}$ & $2.67^{\mathrm{d}}$ \\
\hline 3 days & $28.42^{\mathrm{a}}$ & $6.96^{\mathrm{a}}$ & $2.36^{\mathrm{a}}$ & $110.07^{a}$ & $18.77^{\mathrm{a}}$ & $0.72^{b}$ & $3.61^{c}$ \\
\hline 7 days & $27.30^{c}$ & $6.60^{\mathrm{a}}$ & $2.10^{\mathrm{a}}$ & $110.21^{a}$ & $18.55^{\mathrm{a}}$ & $0.69^{c}$ & $4.45^{b}$ \\
\hline 10 days & $27.79^{b}$ & $7.23^{a}$ & $2.41^{\mathrm{a}}$ & $112.65^{a}$ & $18.53^{\mathrm{a}}$ & $0.73^{b}$ & $4.78^{\mathrm{a}}$ \\
\hline$p$-value & $<0.01$ & 0.26 & 0.22 & 0.11 & 0.30 & $p<0.01$ & $<0.01$ \\
\hline
\end{tabular}

Note: Mean values within the same column with different letters are significantly $(p<0.05)$ different by Duncan's Multiple Range test (DMRT). 
Supply chain scenario D (simulated 'abusive' treatment of fruit within the export chain)

Significant changes $(p<0.01)$ in color attribute (L) for lightness were observed, (Table 12), with berries becoming lighter with increased temperature and lower humidity and darker when returned to lower temperatures and increased humidity. No significant difference in color attributes $\mathrm{a}^{*}(p=0.86)$ and $\mathrm{b}^{*}(p=0.21)$ were observed. The average berry firmness remained unchanged $(p=0.23)$. There were significant changes observed in TSS $(p<0.01)$ with values increasing and TA values $(p<0.01)$ that decreased during storage. Stem color changed significantly over time $(p<0.01)$. While stems remained fresh and green during the 28 days in cold storage, the 2 days at ambient conditions, to simulate the abusive treatment, affected the stems to such an extent that by the time they reached retail conditions, most of the stems were already brown.

Table 12. Supply chain scenario D (2018): changes in quality attributes of color ( $L$, $a^{*}$ and $\left.b^{*}\right)$, firmness (N), TSS $\left(\right.$ Brix $\left.^{\circ}\right)$, TA (\%), and stem browning index for 'Crimson Seedless' table grapes at harvest after 28 days cold storage $\left(-0.3 \pm 0.7^{\circ} \mathrm{C}, 81.3 \pm 4.1 \% \mathrm{RH}\right)$, after 2 days 'abusive' temperature and humidity $\left(25.1 \pm 1.3{ }^{\circ} \mathrm{C}\right.$ and $\left.46.6 \pm 6.0 \% \mathrm{RH}\right)$, after another 10 days at retail conditions $\left(5.4 \pm 0.6^{\circ} \mathrm{C}, 83.7 \pm 2.9 \% \mathrm{RH}\right)$ and then for 3,7 and 10 days at ambient conditions $\left(25.1 \pm 1.3^{\circ} \mathrm{C}\right.$ and $46.6 \pm 6.0 \% \mathrm{RH})$. Mean values with different letter(s) in the same column indicate statistically significant differences $(p<0.05)$.

\begin{tabular}{|c|c|c|c|c|c|c|c|}
\hline \multicolumn{8}{|c|}{2018} \\
\hline Time & $\mathbf{L}^{*}$ & $a^{*}$ & $\mathbf{b}^{*}$ & $\begin{array}{l}\text { Firmness } \\
(\mathrm{N})\end{array}$ & $\begin{array}{c}\text { TSS } \\
\left(\text { Brix }^{\circ}\right)\end{array}$ & $\begin{array}{l}\text { TA } \\
(\%)\end{array}$ & $\begin{array}{c}\text { Stem Browning } \\
\text { Index }\end{array}$ \\
\hline Harvest & $27.46^{b}$ & $7.91^{a}$ & $9.36^{a}$ & $116.60^{a}$ & $17.80^{\mathrm{d}}$ & $0.79^{a}$ & $1^{\mathrm{e}}$ \\
\hline $\begin{array}{l}28 \text { days } \\
\left(-0.5^{\circ} \mathrm{C}\right)\end{array}$ & $27.49^{b}$ & $7.89^{a}$ & $9.16^{a}$ & $118.54^{\mathrm{a}}$ & $18.54^{\mathrm{c}}$ & $0.76^{b}$ & $1.89^{\mathrm{e}}$ \\
\hline $\begin{array}{l}2 \text { days } \\
\text { (ambient) }\end{array}$ & $28.21^{a}$ & $7.65^{a}$ & $9.23^{a}$ & $115.72^{a}$ & $17.75^{\mathrm{d}}$ & $0.75^{b}$ & $3.25^{\mathrm{d}}$ \\
\hline 10 days $\left(5^{\circ} \mathrm{C}\right)$ & $27.71^{b}$ & $7.88^{a}$ & $9.54^{\mathrm{a}}$ & $123.01^{\mathrm{a}}$ & $19.55^{\mathrm{ab}}$ & $0.72^{\mathrm{c}}$ & $4.01^{\mathrm{c}}$ \\
\hline 3 days & $27.60^{b}$ & $8.02^{a}$ & $8.72^{a}$ & $121.96^{\mathrm{a}}$ & $17.27^{\mathrm{d}}$ & $0.72^{c}$ & $4.62^{b}$ \\
\hline 7 days & $28.23^{a}$ & $7.69^{a}$ & $8.34^{\mathrm{a}}$ & $116.28^{a}$ & $19.11^{b}$ & $0.75^{b}$ & $4.94^{\mathrm{a}}$ \\
\hline 10 days & $27.82^{b}$ & $7.83^{a}$ & $8.12^{a}$ & $123.24^{\mathrm{a}}$ & $19.74^{\mathrm{a}}$ & $0.76^{b}$ & $4.94^{\mathrm{a}}$ \\
\hline$p$-value & $<0.01$ & 0.86 & 0.21 & 0.23 & $<0.01$ & $<0.01$ & $<0.01$ \\
\hline
\end{tabular}

Note: Mean values within the same column with different letters are significantly $(p<0.05)$ different by Duncan's Multiple Range test (DMRT).

\subsection{Socioeconomic Impacts of Postharvest Losses}

Based on the percentage losses along the simulated supply chains, estimates were made to determine the volume of table grapes that could be lost at the national level (Table 13). In 2017, South Africa produced approximately 325,061 tons, of which 20,046 tons were sold locally, and 305,015 tons were exported [17]. The ranges provided in the following data are estimates made from the lowest losses which were recorded in the 2018 season to the highest losses that were recorded in 2017. It thus provides a range of losses that could occur in any given season.

Supply chain scenario A (marketing at ambient temperatures and relative humidity)

Losses translated were between 555 and 1052 tons after 3 days. This equates to a financial loss of R7.3 million-R13.8 million, 3,623,595-6,868,508 MJ of energy, 116,744$221,288 \mathrm{~m}^{3}$ water used in production and 505-957 tons $\mathrm{CO}_{2}$ eq emissions. After 7 days, the losses increase to 575-1904 tons, R7.5 million-R25 million, 375,417-12,431,216 MJ, $120,951-400,466 \mathrm{~m}^{3}$ and 523-1733 tons $\mathrm{CO}_{2}$ eq. After 10 days, 1305-2068 tons were lost, R17.1 million-R27.1 million, 8,520,345-13,461,972 MJ of energy, 274,507-435,003 $\mathrm{m}^{3}$ and 1188-1882 tonnes $\mathrm{CO}_{2}$ eq. 
Table 13. Impact of postharvest losses in terms of magnitude, monetary value, energy used, water footprint, and greenhouse gas emissions in the production and distribution of table grapes along different supply chains.

\begin{tabular}{|c|c|c|c|c|c|c|c|c|}
\hline \multirow[t]{2}{*}{ Year } & \multirow[t]{2}{*}{$\begin{array}{l}\text { Supply Chain } \\
\text { Scenario }\end{array}$} & \multicolumn{2}{|r|}{ Storage Condition } & \multicolumn{2}{|c|}{$\begin{array}{l}\text { Estimated Physical and } \\
\text { Economic Losses }\end{array}$} & \multicolumn{3}{|c|}{${ }^{*}$ Estimated Environmental and Resource Impacts } \\
\hline & & Time & Temp $\left({ }^{\circ} \mathrm{C}\right)$ and Humidity $(\%)$ & $\begin{array}{l}\text { Physical } \\
\text { (ton) }\end{array}$ & Value (ZAR) & Energy (MJ) & $\begin{array}{c}\text { Water } \\
\text { Footprint }\left(\mathrm{m}^{3}\right)\end{array}$ & $\begin{array}{c}\text { Emissions } \\
\mathrm{CO}_{2} \text { eq (ton) }\end{array}$ \\
\hline 2017 & A & 3 days & $25.1 \pm 1.3^{\circ} \mathrm{C} ; 46.6 \pm 6.0 \% \mathrm{RH}$ & $1052^{\mathrm{a}}$ & $13,816,968^{a}$ & $6,868,508^{a}$ & $221,288^{a}$ & $957^{\text {a }}$ \\
\hline 2017 & A & 7 days & $25.1 \pm 1.3^{\circ} \mathrm{C} ; 46.6 \pm 6.0 \% \mathrm{RH}$ & $1904^{\mathrm{b}}$ & $25,007,316^{\mathrm{b}}$ & $12,431,216^{\mathrm{b}}$ & $400,466^{b}$ & $1733^{b}$ \\
\hline 2017 & A & 10 days & $25.1 \pm 1.3^{\circ} \mathrm{C} ; 46.6 \pm 6.0 \% \mathrm{RH}$ & $2068^{\mathrm{b}}$ & $27,161,112^{\mathrm{b}}$ & $13,461,972^{\mathrm{b}}$ & $435,003^{\mathrm{b}}$ & $1882^{\mathrm{b}}$ \\
\hline 2017 & B & 14 days & $-0.3 \pm 0.7^{\circ} \mathrm{C} ; 81.3 \pm 4.1 \% \mathrm{RH}$ & $493^{\mathrm{a}}$ & $6,475,062^{\text {a }}$ & $3,218,797^{\mathrm{a}}$ & $103,703^{\text {a }}$ & $449^{\text {a }}$ \\
\hline 2017 & B & 10 days & $5.4 \pm 0.6^{\circ} \mathrm{C} ; 83.7 \pm 2.9 \% \mathrm{RH}$ & $874^{\mathrm{ab}}$ & $11,479,116^{\mathrm{ab}}$ & $5,706,346^{\mathrm{ab}}$ & $183,846^{\mathrm{ab}}$ & $795^{\mathrm{ab}}$ \\
\hline 2017 & B & 3 days & $25.1 \pm 1.3^{\circ} \mathrm{C} ; 46.6 \pm 6.0 \% \mathrm{RH}$ & $1431^{\mathrm{bc}}$ & $18,794,754^{\text {bc }}$ & $9,342,999$ bc & $301,011^{b c}$ & $1302^{b c}$ \\
\hline 2017 & B & 7 days & $25.1 \pm 1.3^{\circ} \mathrm{C} ; 46.6 \pm 6.0 \% \mathrm{RH}$ & $2074^{\text {cd }}$ & $27,239,916^{\mathrm{cd}}$ & $13,541,146^{\mathrm{cd}}$ & $436,266^{\mathrm{cd}}$ & $1887^{\mathrm{cd}}$ \\
\hline 2017 & B & 10 days & $25.1 \pm 1.3^{\circ} \mathrm{C} ; 46.6 \pm 6.0 \% \mathrm{RH}$ & $2534^{\mathrm{d}}$ & $33,281,556^{d}$ & $16,544,486^{d}$ & $533,027^{\mathrm{d}}$ & $2306^{d}$ \\
\hline 2017 & C & 28 days & $-0.3 \pm 0.7^{\circ} \mathrm{C} ; 81.3 \pm 4.1 \% \mathrm{RH}$ & $13,299^{\text {a }}$ & $279,305,598^{\text {a }}$ & $86,829,171^{\text {a }}$ & $2,797,445^{\text {a }}$ & $12,102^{a}$ \\
\hline 2017 & C & 10 days & $5.4 \pm 0.6^{\circ} \mathrm{C} ; 83.7 \pm 2.9 \% \mathrm{RH}$ & $21,443^{\mathrm{b}}$ & $450,345,886^{\mathrm{b}}$ & $140,001,347^{\mathrm{b}}$ & $4,510,535^{\mathrm{b}}$ & $19,513^{b}$ \\
\hline 2017 & $\mathrm{C}$ & 3 days & $25.1 \pm 1.3^{\circ} \mathrm{C} ; 46.6 \pm 6.0 \% \mathrm{RH}$ & $22,602^{\mathrm{b}}$ & $474,687,204^{\text {b }}$ & $147,568,458^{\mathrm{b}}$ & $4,754,331^{\mathrm{b}}$ & $20,568^{\mathrm{b}}$ \\
\hline 2017 & $\mathrm{C}$ & 7 days & $25.1 \pm 1.3^{\circ} \mathrm{C} ; 46.6 \pm 6.0 \% \mathrm{RH}$ & $29,251^{\mathrm{b}}$ & $614,329,502^{\mathrm{b}}$ & $190,979,779^{\mathrm{b}}$ & $6,152,948^{\mathrm{b}}$ & $26,618^{b}$ \\
\hline 2017 & $\mathrm{C}$ & 10 days & $25.1 \pm 1.3^{\circ} \mathrm{C} ; 46.6 \pm 6.0 \% \mathrm{RH}$ & $43,587^{c}$ & $915,414,174^{\mathrm{c}}$ & $284,579,523^{\mathrm{c}}$ & $9,168,525^{\mathrm{c}}$ & $39,664^{\mathrm{c}}$ \\
\hline 2018 & A & 3 days & $25.1 \pm 1.3^{\circ} \mathrm{C} ; 46.6 \pm 6.0 \% \mathrm{RH}$ & $555^{\mathrm{a}}$ & $7,289,370^{\mathrm{a}}$ & $3,623,595^{\mathrm{a}}$ & $116,744^{\mathrm{a}}$ & $505,05^{\mathrm{a}}$ \\
\hline 2018 & A & 7 days & $25.1 \pm 1.3^{\circ} \mathrm{C} ; 46.6 \pm 6.0 \% \mathrm{RH}$ & $575^{\mathrm{a}}$ & $7,552,050^{\mathrm{a}}$ & $3,754,175^{\mathrm{a}}$ & $120,951^{\text {a }}$ & $523,25^{\text {a }}$ \\
\hline 2018 & A & 10 days & $25.1 \pm 1.3^{\circ} \mathrm{C} ; 46.6 \pm 6.0 \% \mathrm{RH}$ & $1305^{\mathrm{b}}$ & $17,139,870^{\mathrm{b}}$ & $8,520,345^{\mathrm{b}}$ & $274,507^{\mathrm{b}}$ & $118,755^{\mathrm{b}}$ \\
\hline 2018 & B & 14 days & $-0.3 \pm 0.7^{\circ} \mathrm{C} ; 81.3 \pm 4.1 \% \mathrm{RH}$ & $611^{\mathrm{a}}$ & $8,024,874^{\text {a }}$ & $3,989,219^{a}$ & $128,524^{a}$ & $556^{\mathrm{a}}$ \\
\hline 2018 & B & 10 days & $5.4 \pm 0.6^{\circ} \mathrm{C} ; 83.7 \pm 2.9 \% \mathrm{RH}$ & 728 ab & $9,561,552^{a b}$ & $4,753,112^{a b}$ & $153,135^{\mathrm{ab}}$ & $663^{\mathrm{ab}}$ \\
\hline 2018 & B & 3 days & $25.1 \pm 1.3^{\circ} \mathrm{C} ; 46.6 \pm 6.0 \% \mathrm{RH}$ & $1163^{\mathrm{bc}}$ & $15,274,842^{\text {bc }}$ & $7,593,227^{b c}$ & $244,637^{b c}$ & $1058^{\mathrm{bc}}$ \\
\hline 2018 & B & 7 days & $25.1 \pm 1.3^{\circ} \mathrm{C} ; 46.6 \pm 6.0 \% \mathrm{RH}$ & $1303^{\mathrm{cd}}$ & $17,113,602^{\mathrm{cd}}$ & $85,07,287$ cd & $274,086^{\mathrm{cd}}$ & $1186^{\mathrm{cd}}$ \\
\hline 2018 & B & 10 days & $25.1 \pm 1.3^{\circ} \mathrm{C} ; 46.6 \pm 6.0 \% \mathrm{RH}$ & $1856^{\mathrm{d}}$ & $24,376,704^{d}$ & $12,117,824^{\mathrm{d}}$ & $390,410^{d}$ & $1689^{\mathrm{d}}$ \\
\hline 2018 & $\mathrm{C}$ & 28 days & $-0.3 \pm 0.7^{\circ} \mathrm{C} ; 81.3 \pm 4.1 \% \mathrm{RH}$ & $29,861^{\text {a }}$ & $627,140,722^{a}$ & $194,962,469^{a}$ & $6,281,261^{a}$ & $27,174^{\mathrm{a}}$ \\
\hline 2018 & C & 10 days & $5.4 \pm 0.6^{\circ} \mathrm{C} ; 83.7 \pm 2.9 \% \mathrm{RH}$ & $11,560^{\mathrm{b}}$ & $242,783,120^{\mathrm{b}}$ & $75,475,240^{\mathrm{b}}$ & $2,431,646^{\mathrm{b}}$ & $10,520^{\mathrm{b}}$ \\
\hline 2018 & C & 3 days & $25.1 \pm 1.3^{\circ} \mathrm{C} ; 46.6 \pm 6.0 \% \mathrm{RH}$ & $12,109^{\mathrm{b}}$ & $254,313,218^{\mathrm{b}}$ & $79,059,661^{\mathrm{b}}$ & $2,547,128^{\mathrm{b}}$ & $11,019^{b}$ \\
\hline 2018 & $\mathrm{C}$ & 7 days & $25.1 \pm 1.3^{\circ} \mathrm{C} ; 46.6 \pm 6.0 \% \mathrm{RH}$ & 21,107 ab & $443,289,214$ ab & $137,807,603$ ab & $4,439,857^{\mathrm{ab}}$ & 19,207 ab \\
\hline 2018 & C & 10 days & $25.1 \pm 1.3^{\circ} \mathrm{C} ; 46.6 \pm 6.0 \% \mathrm{RH}$ & $31,173^{\mathrm{a}}$ & $654,695,346^{\text {a }}$ & $203,528,517^{\text {a }}$ & $6,557,241^{\text {a }}$ & $2,836,743^{\text {a }}$ \\
\hline 2018 & $\mathrm{D}$ & 28 days & $-0.3 \pm 0.7^{\circ} \mathrm{C} ; 81.3 \pm 4.1 \% \mathrm{RH}$ & $9242^{\mathrm{a}}$ & $194,100,484^{\text {a }}$ & $60,341,018^{a}$ & $1,944,055^{\mathrm{a}}$ & $8410^{\mathrm{a}}$ \\
\hline 2018 & $\mathrm{D}$ & 2 days & $25.1 \pm 1.3^{\circ} \mathrm{C} ; 46.6 \pm 6.0 \% \mathrm{RH}$ & $9730^{\mathrm{a}}$ & $204,349,460^{\text {a }}$ & $63,527,170^{\text {a }}$ & $2,046,706^{\mathrm{a}}$ & $8854^{\mathrm{a}}$ \\
\hline 2018 & $\mathrm{D}$ & 10 days & $5.4 \pm 0.6^{\circ} \mathrm{C} ; 83.7 \pm 2.9 \% \mathrm{RH}$ & 13,024 ab & $273,530,048^{\mathrm{ab}}$ & $85,033,696^{\mathrm{ab}}$ & $2,739,598$ ab & 11,852 ab \\
\hline 2018 & $\mathrm{D}$ & 3 days & $25.1 \pm 1.3^{\circ} \mathrm{C} ; 46.6 \pm 6.0 \% \mathrm{RH}$ & 15,251 bc & $320,301,502$ bc & $99,573,779$ bc & $3,208,048$ bc & $13,878 \mathrm{bc}$ \\
\hline 2018 & $\mathrm{D}$ & 7 days & $25.1 \pm 1.3^{\circ} \mathrm{C} ; 46.6 \pm 6.0 \% \mathrm{RH}$ & $20,314^{c}$ & $426,634,628^{c}$ & $132,630,106^{\mathrm{c}}$ & $4,273,050^{\mathrm{c}}$ & $18,486^{c}$ \\
\hline 2018 & $\mathrm{D}$ & 10 days & $25.1 \pm 1.3^{\circ} \mathrm{C} ; 46.6 \pm 6.0 \% \mathrm{RH}$ & $27,177^{\mathrm{d}}$ & $570,771,354^{\mathrm{d}}$ & $177,438,633^{d}$ & $5,716,682^{d}$ & $24,731^{\mathrm{d}}$ \\
\hline
\end{tabular}

Note: a,b,c Values in a column without a common superscript are significantly different $(p<0.05)$. ${ }^{*}$ Estimated values obtained using the volume of table grapes sold locally, 20,046 $\mathrm{t}$ and exported, 305,015 $\mathrm{t}$ [17]. This section may be divided by subheadings. It should provide a concise and precise description of the experimental results, their interpretation as well as the experimental conclusions that can be drawn.

Supply chain scenario B (to local retail markets)

After 14 days in cold storage, the losses were between 493 and 611 tons with a financial loss of R6.5 million-R8 million, lost energy of 3,218,797-3,989,219 MJ, a water footprint of $103,703-128,524 \mathrm{~m}^{3}$, and $449-556$ tons $\mathrm{CO}_{2}$ eq. After 10 days at retail conditions, losses were 728-874 tons, R9.6 million-R11.5 million, 4,753,112-5,706,346 MJ, 153,135-183,846 m³ water lost, and 663-795 tons $\mathrm{CO}_{2}$ eq.

Once moved to ambient conditions, the losses after 3 days were 1163-1431 tons, R15.2 million-R18.8 million, 7,593,227-9,342,999 MJ, 244,637-301,011 $\mathrm{m}^{3}$, and 1058-1302 tons $\mathrm{CO}_{2}$ eq. After 7 days, 1303-2074 tons, R17.1 million-R27.2 million, 8,507,287-13,541,146 MJ, 274,086-436,266 $\mathrm{m}^{3}$, and 1186-1887 tons CO2eq. After 10 days, 1856-2534 tons, R24.3 millionR33.3 million, $12,117,824-16,544,486 \mathrm{MJ}, 390,410-533,027 \mathrm{~m}^{3}$, and $1689-2306$ tons $\mathrm{CO}_{2}$ eq. 
Supply chain scenario $C$ (to export retail markets)

After 28 days in cold storage, the losses were between 13,299 and 29,861 tons with a financial loss of R279.3 million-R627.1 million, 86,829,171-194,962,469 MJ of energy, $2,797,445-6,281,261 \mathrm{~m}^{3}$ of water, and 12,102-27,174 tons $\mathrm{CO}_{2}$ eq. After 10 days at retail conditions, 11,560-21,443 tons, R242.8 million-R450.3 million, 75,475,240-140,001,347 MJ, 2,431,646$4,510,535 \mathrm{~m}^{3}$, and 10,520-19,513 tons $\mathrm{CO}_{2}$ eq. After 3 days at ambient conditions, losses were 12,109-22,602 tons, R254.3 million-R474.7 million, 79,059,661-147,568,458 MJ, 2,547,1284,754,331 $\mathrm{m}^{3}$ and 11,019-20,568 tons $\mathrm{CO}_{2}$ eq. After 7 days: 21,107-29,251 tons, R443.3 millionR614.3 million, 137,807,603-190,979,779 MJ, 4,439,857-6,152,948 $\mathrm{m}^{3}$, and 19,207-26,618 tons $\mathrm{CO}_{2}$ eq. After 10 days at ambient, the losses were 31,173-43,587 tons, R654.7 million-R915.4 million, 203,528,517-284,579,523 MJ, 6,557,241-9,168,525 m³ and 28,367-39,664 tons $\mathrm{CO}_{2}$ eq.

Supply chain scenario D (simulated 'abusive' treatment of fruit within the export chain)

After 28 days in cold storage, the losses were 9242 tons with a financial value of R194.1 million, 60,341,018 MJ of energy, 1,944,055 $\mathrm{m}^{3}$ water, and 8410 tons $\mathrm{CO}_{2}$ eq. After 2 days at 'abusive' ambient temperature and humidity before entering retail conditions, the losses were 9730 tons, R204.3 million, 63,527,170 MJ, 2,046,706 $\mathrm{m}^{3}$ water, and 8854 tons $\mathrm{CO}_{2}$ eq. After 10 days at retail conditions, losses were 13,024 tons, R273.5 million, $85,033,696 \mathrm{MJ}, 2,739,598 \mathrm{~m}^{3}$, and 11,852 tons $\mathrm{CO}_{2}$ eq. At 3 days of ambient conditions, losses were 15,251 tons, R320.3 million, 99,573,779 MJ, 3,208,048 $\mathrm{m}^{3}$, and 13,878 tons $\mathrm{CO}_{2}$ eq. After 7 days ambient: 20,314 tons, R426.6 million, 132,630,106 MJ, 4,273,050 m and 18,486 tons $\mathrm{CO}_{2}$ eq. After 10 days at ambient conditions, the losses were 27,177 tons, R570.8 million, $177,438,633 \mathrm{MJ}, 5,716,682 \mathrm{~m}^{3}$, and 24,731 tons $\mathrm{CO}_{2}$ eq.

\section{Discussion}

\subsection{Physical Losses at Farm Level}

The losses measured on farm level in 2017 were higher than the findings of [35], who concluded in an economic analysis of the South African table grape supply chain that approximately $9.5 \%$ was lost between farm and intake. However, the data used in that study was based on perception data gathered from different role-players in the table grape industry, the authors own elaborations and from [18] as no primary data was collected.

The authors of [36] reported similar losses at agricultural production level of $15 \%$, where table grape losses were quantified along the supply chain in Iran. The materials and methods of that study are unclear, however, as it divides the supply chain into production, postharvest, processing, distribution, and consumption stages without clearly describing the various stages. In the present study, the losses at farm level include what it seems they refer to as production, postharvest and processing into one. If that is the case, the losses experienced in Iran were much higher than our findings and amounted to $46 \%$ of total production. In [36], the authors used data from government and private sources with estimates and interviews, and no primary data was collected in that study.

In the present study, the average loss measured on farm level in 2018 was $5.97 \%$. This is less than reported by $[35,36]$ but very similar to the findings of [37] that reported losses of table grapes in Pakistan of 4.8\% at farm level and [38] where losses of table grapes at farm level in India were reported as 3.4\% for grapes prepared for the domestic market while grapes prepared for the export market sustained losses of $7.82 \%$ as the requirements for export produce are stricter.

The losses measured in 2017 are similar to that of [38] for export grapes (Thomson Seedless), but the reasons for the losses differ, water berries (6.72\%), harvest injury $(0.57 \%)$, mummies $(0.02 \%)$, and immature $(0.26 \%)$. The authors of [39] report losses of table grape (Nana Purple) on farm level as $8-10 \%$ due to insufficient coloring, while in $[36,37]$ the authors do not specify the reasons for losses.

The large differences between farms in 2017, were unexpected and although it was initially thought that it could have been due to different climatic conditions or soil types it appears to have been related to different vineyard management practices as there was no statistical difference between losses on the farms in the 2018 season and the average 
losses were less than half recorded in 2017. The reasons for this could be two-fold. Firstly, by having been made aware of how high the losses were during the previous season, the farm managers took steps to reduce this during the 2018 season, workers were trained to be more careful when handling the crates after harvest. Secondly, the farm that sustained the highest losses (23.3\%) in 2017 harvested later than was optimal and therefore the bunches stayed on the vines too long. The 2018 harvest occurred two weeks earlier than in 2017, and the grapes were in better condition leading to fewer losses on farm level.

\subsection{Physical Losses along the Simulated Supply Chain}

Supply chain scenario A (handling and marketing fruit under ambient conditions)

These results support the research of [40] that reported the mass of grapes cv. 'Crimson Seedless' always decreased with time at all combinations of storage temperature and $\mathrm{RH}$. Grapes stored at higher temperature lost weight faster than those maintained at lower temperatures. The increased vapor pressure deficit and respiration rates of the stems of grapes stored at higher temperatures accelerated transpiration rates of fruit. In [19], the authors further found a linear profile for the mass decreasing in grapes of cv. 'Thompson' and 'Superior'. Similar findings were also reported by [39], noting a 5\% weight loss in grapes transported in trucks in temperatures of $35-40{ }^{\circ} \mathrm{C}$ before reaching the wholesale market.

The findings on the incidence of decay were similar to the findings of [20], who found a severe incidence of decay ( $2-5$ infected berries per carton) of 'Regal Seedless' table grapes after 7 days shelf life at $24.33 \pm 0.04{ }^{\circ} \mathrm{C}$ in similar packaging to that used in this study. The authors of [41] reported much higher levels of $40.5 \%$ after 7 days at $15{ }^{\circ} \mathrm{C}$ for cv 'Thompson Seedless'. Visible decay in a carton could make the carton hard to sell, even though less than $10 \%$ of the berries are affected, as from the consumer's perspective, appearance is the first factor that influences purchase decision, followed by perceived value for money and fruit eating quality [42]. This is similar to the findings of [20] who found severe incidence of decay ( $2-5$ infected berries per carton) of 'Regal Seedless' table grapes after 7 days shelf life at $24.33 \pm 0.04{ }^{\circ} \mathrm{C}$ in similar packaging to that used in this study. The authors of [41] reported much higher levels of $40.5 \%$ after 7 days at $15{ }^{\circ} \mathrm{C}$ for cv 'Thompson Seedless'. Visible decay in a carton could make the carton hard to sell, even though less than $10 \%$ of the berries are affected, as from the consumer's perspective, appearance is the first factor that influences purchase decision, followed by perceived value for money and fruit eating quality [42].

Supply chain scenario B (to local retail markets)

After 10 days at retail conditions, the reported decay was less than half the amount of $4.56 \%$ reported by [38]. Similar to [43] reporting $1 \% \mathrm{SO}_{2}$ damage for $\mathrm{cv}$ 'Red Globe' after 15 days in cold storage, the incidence of $\mathrm{SO}_{2}$ berry damage in this study was $1 \%$ after 14 days in cold storage. The authors of $[20,44]$ reported that the combination of free water $(100 \% \mathrm{RH})$, as occurs with the formation of condensation when cartons are removed from cooler conditions to ambient conditions, combined with $\mathrm{SO}_{2}$ in nonperforated liners may result in the formation of acidic conditions that may increase $\mathrm{SO}_{2}$ injury, this seems to be the case in this study also. It is suggested that after a few days at ambient conditions, the free water evaporates, and the damage stops. Based on the investigated seasons, the decreases of $5.4 \%$ and $6.8 \%$ in weight noted for the two seasons were more than double the amount of $2 \%$ weight loss after 14 days of cold storage for cv. 'Thompson Seedless' reported by [45], while findings on decay during cold storage were similar to the $0 \%$ decay reported.

Supply chain scenario $C$ (to export retail markets)

The measured weight loss was similar to the $5 \%$ after 10 days and $10 \%$ after 14 days at room temperature $\left(25^{\circ} \mathrm{C}\right)$ and $45-70 \%$ relative humidity reported by [46] for $\mathrm{cv}$ 'Victoria'. After 28 days in cold storage $\left(-0.3 \pm 0.7^{\circ} \mathrm{C}, 81.3 \pm 4.1 \% \mathrm{RH}\right)$, there was a $2.14 \%$ incidence of decay in 2017 and $0.94 \%$ in 2018. These results were similar the mean of $1.28 \%$ decay reported by [47] for cultivars 'Red Globe', 'Sunred Seedless' and 'Thompson Seedless' under similar conditions for the same time period. After 10 days at retail display conditions 
$\left(5.4 \pm 0.6{ }^{\circ} \mathrm{C}, 83.7 \pm 2.9 \% \mathrm{RH}\right)$ this increased to $3.2 \%$ in 2017 and $2.6 \%$ in 2018 . These results were slightly higher than the $2.5 \%$ reported by [35] for the perceived losses of table grapes at retail level and correspond to the lowest end of the 3-7\% range of loss reported for fresh fruit under retail conditions in the UK and Spain by [48]. Both [35,48], however, used data collected through interviews with managers in food manufacturing and questionnaires completed by other role players in the table grape supply chain while no primary sampling data was collected. Three days after being moved to ambient temperature and humidity conditions $\left(25.1 \pm 1.3{ }^{\circ} \mathrm{C}\right.$ and $\left.46.6 \pm 6.0 \% \mathrm{RH}\right)$, decay increased to $4.44 \%$ in 2017 and $3.16 \%$ in 2018. The authors of [49] reported decay of more than a hundred berries per $\mathrm{kg}$ after 4 weeks at $0{ }^{\circ} \mathrm{C}$ and 3 days shelf-life at $20^{\circ} \mathrm{C}$ for cv. 'Thompson Seedless'. Taking the average weight of a 'Thompson Seedless' berry as $5 \mathrm{~g}$ reported [50] the data translates to $500 \mathrm{~g}$ infected berries per $\mathrm{kg}$ or $50 \%$. That is much higher than the decay rate measured in this study. The results for $\mathrm{SO}_{2}$ damage seem similar to the rating of 4 (11-20 berries per replicate consisting of 10 bunches) with $\mathrm{SO}_{2}$ damage after 65 days at $0{ }^{\circ} \mathrm{C}$ and 3 days at $20^{\circ} \mathrm{C}$ reported by [51] although it is not easy to compare as that study used a rating of 1-5 for describing $\mathrm{SO}_{2}$ damage and not $\%$ and it is unknown exactly how many berries were in a replicate of 10 bunches.

Supply chain scenario D (simulated 'abusive' treatment of fruit within the export chain)

The $5.7 \%$ decrease in weight noted is half the weight loss of around $12 \%$ reported by [52] for 'Crimson Seedless' table grapes under similar conditions and for the same time period.

Decay and $\mathrm{SO}_{2}$ damage are disorders that can be caused or aggravated by wet berries in combination with elevated temperature [53]. Results indicate that the decay in this trial was lower than that recorded for supply chain scenario $C$, which was the same in all regards except for the 2 days under ambient conditions. This could be due to condensation evaporating, leaving less free moisture that would exacerbate decay.

\section{Total Amount of Physical Losses}

Supply chain scenario A (marketing at ambient conditions)

For both years, the losses were considerably less than the $53 \%$ reported by [36] for table grape losses along the supply chain under ambient conditions in Iran. No sampling data was recorded in that study. However, the data used for their calculations were collected through government and private data sources with horticulture expert estimates, grape grower interviews, agriculture cooperation interviews, and market consultations.

Supply chain scenario B (to local retail markets)

When these losses are taken only from harvest to retail level, it translates to $18.26 \%$ loss in 2017 and $9.62 \%$ in 2018. The result for 2018 is similar to [38], who reported losses of $7.96 \%$ from the field to retailer in India.

Supply chain scenario C (to export retail markets)

The 2018 data was similar to [38] reporting export supply chain losses for table grapes in India, of $19.95 \%$, as well as the approximate figure of $15.5 \%$ reported by [35] for the South African table grape supply chain, although no sampling data was collected for those studies. The 2017 data of this study was significantly higher and showed how variable the yearly losses could be.

Supply chain scenario D (simulated 'abusive' treatment of fruit within the export chain)

In terms of quantity of losses, therefore, the 2 days at ambient conditions in the middle of the cold chain did not cause a significant difference. It did, however, create a difference in quality, as will be illustrated in the next section.

\subsection{Quality Losses along the Supply Chain}

Supply chain scenario A (marketing at ambient conditions)

Results for firmness over time supports the findings of [23] reporting no difference in firmness for cv. 'Mystery' after 6 days under ambient conditions $\left(22-28^{\circ} \mathrm{C}\right)$ but contrasts with the findings of [54] for $\mathrm{cv}$. 'Muscat Hamburg' reporting a significant decrease of 
firmness over time under ambient conditions. Similar findings of unchanging TSS and TA values were reported for both cv. Müşküle and cv. Red Globe by [27] during the first week of that research project. The results on change in stem color support the report by [19]. The author reported major rachis browning during marketing at ambient temperatures and relative humidity.

Supply chain scenario B (to local retail markets)

The increase in lightness measured in 2018 differ to the findings of [45] that found the L values for the black table grape cv. 'Alphonse Lavallée' decrease during cold storage, indicating that the grapes became darker over time. Berry firmness results that showed no significant difference over time is similar to findings of [55] reporting no significant difference in firmness for cv. 'Italia' after cold storage and 7 days shelf life. The increase in TA measured during the 2018 season is similar [27] also describing such a significant increase in TA after 2 and 3 weeks in storage for cv. Müşküle and cv. Red Globe. The authors of $[23,56]$ describe increases in TSS of grapes during cold storage due to water loss. In contrast to the 2018 findings, yet similar to the 2017 findings of this study, TSS levels could remain stable under different storage conditions and for different cultivars. In [24] the authors reported that TSS levels in cv. Red Globe, after up to 12 weeks in storage under different controlled atmosphere $(\mathrm{CA})$ conditions at $0{ }^{\circ} \mathrm{C}$, was almost equal to that measured at harvest.

Supply chain scenario C (to export retail markets)

No significant difference in any of the color attributes were found in 2017, similar to findings of [57] for cv. 'BRS Isis' after 50 days in cold storage plus 5 days under ambient conditions. In 2018, however, results indicated that berry color became lighter, which differs from [28] reporting that L decreased with storage time for cv. 'Thompson Seedless', while [55] reported no significant changes in color for cv. 'Italia' after 50 days of cold storage and 7 days under ambient conditions.

No change in firmness was observed. Similarly, the authors of [55] reported no significant difference in firmness for cv. Italia after up to 50 days in cold storage and 7 days shelf life. No changes were observed in TSS, similar to findings of [43] for cv. 'Red Globe'. Results for changes in TA are similar to findings reported by [28] that berry TA underwent a progressive decrease during storage for cv. 'Thompson Seedless'. Stem color changes support the findings of $[21,53]$ also noted for cv. 'Thompson Seedless' that the average stem condition deteriorated more during the shelf life period than cold storage.

Supply chain scenario D (simulated 'abusive' treatment of fruit within the export chain).

Unchanged berry firmness was also reported by [23] for cv. 'Mystery' and [43] for cv. 'Red Globe'. [19], however, reported a decrease in firmness during shelf life trials for the white grape cultivars 'Superior' and 'Thompson' held in high (>95\%) and low (70\%) relative humidity at 20 or $10{ }^{\circ} \mathrm{C}$ for up to $11 \mathrm{~d}$. Several researchers similarly reported general increases in TSS of grapes during cold storage, including [23,56]. This is attributed to the gluconeogenesis pathway or water loss. The authors of [23] also reported similar findings on stem browning for cv. 'Mystery' where cooling delays of $48 \mathrm{~h}$ resulted in a rachis browning score of 5 , indicating very severe damage.

\subsection{Socioeconomic Impacts of Postharvest Losses}

The socioeconomic impacts of these postharvest losses indicate a financial loss of between R279 million and over R600 million annually for the table grape export industry. The authors of [35] estimated losses of approximately $9.5 \%$ between production and intake stages for the South African table grape industry, translating into a financial loss of R270.5 million with an additional $2.2 \%$ or R93.2 million between intake and export and $3.8 \%$ or R 400,000 between the importer to retail depot. It is unclear how $3.8 \%$ equals R400,000 when it was also stated that 2.2\% equals R93,200,000, the accuracy of the estimates are therefore uncertain. The values given for losses between production and intake does, however, approximate the values this current study recorded for the 2018 season, while the losses during the 2017 season were more than double that amount. 
Additionally, as much as 177.43 million MJ of fossil energy and 4.8 million $\mathrm{m}^{3}$ of freshwater resources were lost. At the Eskom tariff rate of R0.90 per kWh, the lost energy is worth R44.36 million [58]. The fresh water lost could sustain at least 263,013 individuals daily for a whole year at daily minimum usage rate of $0.05 \mathrm{~m}^{3}$ per day. Losses also contribute to unwanted emission of approximately 52,263 tons of $\mathrm{CO}_{2} \mathrm{eq}$, contributing to environmental degradation from greenhouse gases.

\section{Conclusions}

The highest loss in the supply chain was measured at the farm level. It is therefore important to include this stage when studies are conducted on the quantification of postharvest losses. As the main reason for losses at this stage was mechanical damage due to the rough handling of bunches and crates causing berries to drop off the bunches as well as the crushing of berries due to loading too many bunches in crates, these losses could be improved by making workers more aware of the necessity to handle crates with care. The harvest timing is also essential, as delayed harvesting reduces shelf life and results in an increased postharvest loss.

The main quality problem, among all supply chain scenarios, was rachis and stem browning at temperatures higher than $-0.5^{\circ} \mathrm{C}$. This caused berries to drop faster and bunches to look less fresh, as well as causing bunches to weigh less when sold. While $500 \mathrm{~g}$ or $1 \mathrm{~kg}$ punnets are routinely kept at around $5{ }^{\circ} \mathrm{C}$ at the retail level, during peak season $4.5-10 \mathrm{~kg}$ cartons are often stacked on the floor under ambient conditions. Therefore, the table grapes would have a maximum shelf-life of 7 days before the stems have browned, and too many berries per bunch are decayed to sell. It would be advisable to keep cartons at $-5{ }^{\circ} \mathrm{C}$ and high $\mathrm{RH}$ and only place bunches in punnets in $5{ }^{\circ} \mathrm{C}$ display fridges as the stock sells.

The increase in weight loss and especially stem browning recorded in Scenario D ('abusive' treatment of fruit within the export chain), compared to Scenario $C$ (shipping to export markets) indicated the importance of eliminating the delay between reefer delivery and quality checking as a break in the cold chain of 2 days has a significant impact on the quality of the bunches and therefore also the price it can be sold at.

This study was conducted on farms with good infrastructure, cultivation practices and cooling facilities, where nonetheless, farm-level losses of up to $23 \%$ were recorded. It is significant that during preseason interviews with farm management, the highest estimate of losses was 13\%, most of them lower. As 'Crimson Seedless' is a high value crop, even relatively small improvements in future could have a large financial impact for producer-exporters.

In the changing local agricultural environment of many more upcoming farmers entering the industry, this situation deserves much more attention than what was the case so far. On a global level, as we are approaching population levels of around nine billion people, the choice is obvious: not only must we produce more food, but we should also waste much less.

Author Contributions: Conceptualization, U.L.O.; Formal analysis, A.B.; Funding acquisition, U.L.O.; Investigation, A.B.; Methodology, A.B., U.L.O., O.A.F.; Supervision, O.A.F. and U.L.O.; Validation, O.A.F. and U.L.O.; Visualization, A.B.; Writing-original draft, A.B.; Writing-review and editing, A.B., U.L.O., O.A.F. All authors have read and agreed to the published version of the manuscript.

Funding: This work is based on the research supported wholly/in part by the National Research Foundation of South Africa (Grant Numbers: 64813).

Institutional Review Board Statement: Not applicable.

Informed Consent Statement: Not applicable. 
Data Availability Statement: Design of the study; in the collection, analyses, or interpretation of data; in the writing of the manuscript, or in the decision to publish the results. The opinions, findings and conclusions or recommendations expressed are those of the author(s) alone, and the NRF accepts no liability whatsoever in this regard.

Acknowledgments: The authors offer their heartfelt thanks to the Karsten Group.

Conflicts of Interest: The authors declare no conflict of interest.

\section{References}

1. Kuhr, R.J. Integrated pest management. A new strategy in an old war. N. Y. Food Life Sci. 1979, 12, 3.

2. FAO. State of Food Insecurity in the World: Economic Crises-Impacts and Lessons Learned; Food and Agriculture Organization of the United Nations: Rome, Italy, 2009. Available online: https://www.fao.org (accessed on 12 September 2020).

3. Hodges, R.J.; Buzby, J.C.; Bennett, B. Postharvest losses and waste in developed and less developed countries: Opportunities to improve resource use. J. Agric. Sci. 2010, 149, 37-45. [CrossRef]

4. Alexandratos, N. How to Feed the World in 2050; Expert meeting; FAO Headquarters: Rome, Italy, 2009.

5. FAO. Food Losses and Waste in Europe and Central Asia; Food and Agriculture Organization of the United Nations: Rome, Italy, 2013. Available online: https:/ / www.fao.org (accessed on 11 November 2020).

6. Statista. Global Volume of Wasted Food as of 2017, by Food Category, Global Waste Generation Dossier, Statista. 2019. Available online: https:/ / www.statista.com/study/58790/global-waste-generation/ (accessed on 10 September 2020).

7. Smil, V. Improving Efficiency and Reducing Waste in Our Food System. Environ. Sci. 2004, 1, 17-26. [CrossRef]

8. Parfitt, J.; Barthel, M.; Macnaughton, S. Food waste within food supply chains: Quantification and potential for change to 2050. Phil. Trans. R. Soc. 2010, 365, 3065-3081. [CrossRef] [PubMed]

9. FLW Protocol (Food Loss and Waste Protocol). The Food Loss and Waste Accounting and Reporting Standard; World Resources Institute: Washington, DC, USA, 2016.

10. Lipinski, B.; Hanson, C.; Lomaw, J.; Kitinoja, L.; Waite, R.; Searchinger, T. Reducing Food Loss and Waste; Working Paper; Installment 2 of Creating a Sustainable Food Future; World Resources Institute: Washington, DC, USA, 2013. Available online: http:/ / www.worldresourcesreport.org (accessed on 23 December 2020).

11. Kader, A.A. Increasing availability by reducing post-harvest losses of fresh produce. Acta Hortic. 2005, 682, 2169-2175. [CrossRef]

12. Munhuweyi, K.; Opara, U.L.; Sigge, G. Postharvest losses of cabbages from retail to consumer and the socio-economic and environmental impacts. Br. Food J. 2016, 118, 286-300. [CrossRef]

13. Affognon, H.; Mutungi, C.; Sanginga, P.; Borgemeister, C. Unpacking postharvest losses in Sub-Saharan Africa: A meta-analysis. World Dev. 2015, 66, 49-68. [CrossRef]

14. Oelofse, S.H.H.; Nahman, A. Estimating the magnitude of food waste generated in South Africa. Waste Manag. Res. 2013, 31, 80-86. [CrossRef] [PubMed]

15. Kitinoja, L.; Kader, A.A. Measuring Post-Harvest Losses of Fresh Fruits and Vegetables in Developing Countries; White paper 15-02; Post-harvest Education Foundation: La Pine, OR, USA, 2015.

16. Gustavsson, J.; Cederberg, C.; Sonesson, U.; Van Otterdijk, R.; Meybeck, A. Global Food Losses and Food Waste Section 3.2; Study Conducted for the International Congress “Save Food!” at Interpack2011, Düsseldorf, Germany; FAO Rural Infrastructure and Agro-Industries Division 38: Rome, Italy, 2011.

17. DAFF. A Profile of the South African Table Grapes Market Value Chain. 2017. Available online: http://webapps.daff.gov.za (accessed on 31 August 2019).

18. SATI. South African Table Grape Industry Statistics Booklet. 2016. Available online: http://www.satgi.co.za/Media/Default/ Documents/Booklets/SATI_BOOK_2016.pdf (accessed on 19 August 2020).

19. Lichter, A.; Kaplunov, T.; Zutahy, Y.; Daus, A.; Alchanatis, V.; Ostrovsky, V.; Lurie, S. Physical and visual properties of grape rachis as affected by water vapour pressure deficit. Postharvest Biol. Technol. 2011, 59, 25-33. [CrossRef]

20. Ngcobo, M.E.K.; Opara, U.L.; Thiart, G.D. Effects of packaging liners on cooling rate and quality attributes of table grape (cv Regal Seedless). Packag. Technol. Sci. 2012, 25, 73-84. [CrossRef]

21. Ngcobo, M.E.K.; Delele, M.A.; Opara, U.L.; Meyer, C.J. Performance of multipackaging for table grapes based on airflow, cooling rates and fruit quality. J. Food Eng. 2013, 116, 613-621. [CrossRef]

22. Crisosto, C.H.; Smilanick, J.L.; Dokoozlian, N.K. Table grapes suffer water loss, stem browning during cooling delays. Calif. Agric. 2001, 55, 39-42. [CrossRef]

23. Li, L.; Kaplunov, T.; Zutahy, Y.; Daus, A.; Porat, R.; Lichter, A. The effects of 1-methylcyclopropane and ethylene on postharvest rachis browning in table grapes. Postharvest Biol. Technol. 2015, 107, 16-22. [CrossRef]

24. Crisosto, C.H.; Garner, D.; Crisosto, G. Carbon dioxide-enriched atmospheres during cold storage limit losses from Botrytis but accelerate rachis browning of 'Red Globe' table grapes. Postharvest Biol. Technol. 2002, 26, 181-189. [CrossRef]

25. Jiang, L.; Jin, P.; Wang, L.; Xuan, Y.; Wang, H.; Zheng, Y. Methyl jasmonate primes defense responses against Botrytis cinerea and reduces disease development in harvested table grapes. Sci. Hortic. 2015, 192, 218-223. [CrossRef]

26. Ngcobo, M.E.K.; Delele, M.A.; Pathare, P.B.; Chan, L.; Opara, U.L.; Meyer, C.J. Moisture loss characteristics of fresh table grapes packed in different film liners during cold storage. Biosyst. Eng. 2012, 113, 363-370. [CrossRef] 
27. Sabir, F.K.; Sabir, A. Quality response of table grapes (Vitis vinifera L.) during cold storage to postharvest cap stem excision and hot water treatments. Int. J. Food Sci. Technol. 2013, 48, 999-1006. [CrossRef]

28. Sabir, F.K.; Sabir, A. Extending postharvest quality attributes of grapes (V. vinifera L. cv. 'Thompson Seedless') by preharvest calcium pulverizations. Acta Sci. Pol. Hortorum Cultus 2017, 16, 29-38. [CrossRef]

29. Kitinoja, L.; Al Hassan, H.Y. Identification of appropriate postharvest technologies for small scale horticultural farmers and marketers in Sub-Saharan Africa and South Asia-Part 1. Postharvest losses and quality assessments. Acta Hortic. 2012, 934, 31-40. [CrossRef]

30. Pathare, P.B.; Opara, U.L.; Al-Said, F.A.-J. Colour measurement and analysis in fresh and processed foods: A review. Food Bioprocess Technol. 2013, 6, 36-60. [CrossRef]

31. Chen, L.; Opara, U.L. Texture measurement approaches in fresh and processed foods-A review. Food Res. Int. 2013, 51, 823-835. [CrossRef]

32. Janse van Vuuren, P.F. Regional Resource Flow Model: Fruit Sector Report. GreenCape. 2015. Available online: https://www. green-cape.co.za/assets / Bioeconomy/RRFM-Fruit-sector-report-2014-15.pdf (accessed on 18 October 2020).

33. Steenwerth, K.L.; Strong, E.B.; Greenhut, R.F.; Williams, L.; Kendall, A. Life cycle greenhouse gas, energy and water assessment of wine grape production in California. Int. J. Life Cycle Assess. 2015, 20, 1243-1253. [CrossRef]

34. Kangueehi, G.N. Water Footprint Analysis to Improve Water Use Efficiency in Table Grape (Vitis vinifera L. cv. Crimson Seedless) Production. A South African Case Study. Ph.D. Thesis, Department of Viticulture and Oenology, Faculty of AgriSciences, Stellenbosch University, Stellenbosch, South Africa, 2018.

35. Louw, L. Economic Aspects of Losses and Waste: Case Study of the South African Table Grape Supply Chain. Master' Thesis, Department of Agricultural Economics, Extension and Rural Development, Faculty of Natural and Agricultural Sciences, University of Pretoria, Pretoria, South Africa, 2017.

36. Rajabi, S.; Lashgarara, F.; Omidi, M.; Hosseini, S.J.F. Quantifying the grapes losses and waste in various stages of supply chain. Biol. Forum 2015, 7, 225-229.

37. Aujla, K.M.; Shah, N.A.; Ishaq, M.; Fraooq, A. Post-harvest losses and marketing of grapes in Pakistan. Sarhad J. Agric. 2011, 27, 485-490.

38. Murthy, M.R.K.; Reddy, G.P.; Rao, K.H. Retail marketing of fruits and vegetables in India: A case study on export of grapes from Andhra Pradesh, India. Eur. J. Logist. Purch. Supply Chain Manag. 2014, 2, 62-70.

39. Sharma, A.K.; Sawant, S.D.; Somkuwar, R.G.; Naik, S. Postharvest Losses in Grapes: Present Indian Status; Technical report ICAR; National Research Centre for Grapes: Pune, India, 2018. Available online: https:/ /www.researchgate.net/publication/311693568 (accessed on 5 August 2020).

40. Pereira, E.; e Silva, R.G.B.; Spagnol, W.A.; Silveira Junior, V. Water loss in table grapes: Model development and validation under dynamic storage conditions. Food Sci. Technol. Camp. 2018, 38, 473-479. [CrossRef]

41. Mlikota Gabler, F.; Fassel, R.; Mercier, J.; Smilanick, J.L. Influence of temperature, inoculation interval, and dosage on biofumigation with Muscodor albus to control postharvest gray mold on grapes. Plant Dis. 2006, 90, 1019-1025. [CrossRef]

42. Eccher Zerbini, P. The quality of pear fruits. Acta Hortic. 2002, 596, 805-810. [CrossRef]

43. Sortino, G.; Allegra, A.; Passafiume, R.; Gianguzzi, G.; Gullo, G.; Gallotta, A. Postharvest Application of Sulphur Dioxide Fumigation to Improve Quality and Storage Ability of "Red Globe" Grape Cultivar During Long Cold Storage. Chem. Eng. Trans. 2017, 58, 403-408.

44. Zoffoli, F.P.; Latorre, B.A.; Naranjo, P. Hairline, a postharvest cracking disorder in table grapes induced by sulfur dioxide. Postharvest Biol. Technol. 2008, 47, 90-97. [CrossRef]

45. Sabir, F.K.; Sabir, A.; Unal, S.; Taytak, M.; Kucukbasmaci, A.; Bilgin, O.F. Postharvest quality extension of minimally processed table grapes by chitosan coating. Int. J. Fruit Sci. 2019, 19, 347-358. [CrossRef]

46. Xu, W.; Li, D.; Fu, Y.; Liu, Z.; Wang, Y.; Yu, X.; Shang, W. Chinese Packaging Institute-2012 Conference Extending the Shelf Life of Victoria Table Grapes by High Permeability and Fungicide Packaging at Room Temperature. Packaging Technol. Sci. 2013, 26, 43-50. [CrossRef]

47. Klaasen, J.A.; Van der Merwe, J.A.; Vries, F.A.; Calitz, F.J. Long-Term Storage Quality of Table Grapes as Influenced by Pre-Harvest Yeast Applications and Post-Harvest Use of Controlled Atmosphere. S. Afr. J. Enol. Vitic. 2006, 27, 2. [CrossRef]

48. Mena, C.; Adenso-Diaz, B.; Yurt, O. The causes of food waste in the supplier-retailer interface: Evidences from the UK and Spain. Resour. Conserv. Recycl. 2011, 55, 648-658. [CrossRef]

49. Lichter, A.; Zutkhy, Y.; Sonego, L.; Dvir, O.; Kaplunov, T.; Sarig, P.; Ben-Arie, R. Ethanol controls postharvest decay of table grapes. Postharvest Biol. Technol. 2002, 24, 301-308. [CrossRef]

50. Peacock, B.; Simpson, T. The Relationship between Berry Weight, Length and Width for Five Table Grape Varieties. Cooperative Extension Pub.-TBI 95. 2017. Available online: http:/ / cetulare.ucanr.edu/files/82015.pdf (accessed on 10 July 2020).

51. Lichter, A.; Zutahy, Y.; Kaplunov, T.; Lurie, S. Evaluation of table grape storage in boxes with sulfurdioxide releasing pads with either an internal plastic liner or external wrap. HortTechnology 2008, 18, 206-214. [CrossRef]

52. Palou, L.; Serrano, M.; Martínez-Romero, D.; Valero, D. New approaches for quality retention of table grapes. Fresh Prod. 2010, 4, 103-110.

53. Du Plessis, S.F. Effects of Packaging and Postharvest Cooling on Quality of Table Grapes (Vitis vinifera L.). Master' Thesis, Department of Horticulture, Faculty of AgriSciences, Stellenbosch University, Stellenbosch, South Africa, 2003. 
54. Tamizheezham, U.; Muthuvel, I.; Subbiah, A. Effect of Temperature on Shelf life of Muscat Hamburg Grapes under Storage. Madras Agric. J. 2018, 105, 426-429. [CrossRef]

55. Ahmed, S.; Roberto, S.R.; Domingues, A.R.; Shahab, M.; Junior, O.J.C.; Sumida, C.H.; De Souza, R.T. Effects of Different Sulfur Dioxide Pads on Botrytis Mold in 'Italia' Table Grapes under Cold Storage. Horticulturae 2018, 4, 29. [CrossRef]

56. Sabir, A.; Sabir, F.K.; Kara, Z. Effects of modified atmosphere packing and honey dip treatments on quality maintenance of minimally processed grape $c v$. Razaki (V. vinifera L.) during cold storage. J. Food Sci Technol. 2011, 48, 312-318. [CrossRef] [PubMed]

57. Colombo, R.C.; Carvalho, D.U.; Da Cruz, M.A.; Sumida, C.H.; Ahmed, S.; Bassoli, P.A.; De Souza, R.T.; Roberto, S.R. Cold Storage and Biocontrol Agents to Extend the Storage Period of 'BRS Isis' Seedless Table Grapes. Horticulturae 2018, 4, 18. [CrossRef]

58. Eskom. Available online: https://www.eskom.co.za/CustomerCare/TariffsAndCharges/Pages/Tariffs_And_Charges.aspx (accessed on 10 October 2019). 